\title{
Phylogenetics of Bonamia parasites based on small subunit and internal transcribed spacer region ribosomal DNA sequence data
}

\author{
Kristina M. Hill ${ }^{1,7}$, Nancy A. Stokes ${ }^{1}$, Stephen C. Webb ${ }^{2}$, P. Mike Hine ${ }^{3}$, \\ Marina A. Kroeck ${ }^{4}$, James D. Moore ${ }^{5}$, Margaret S. Morley ${ }^{6}$, Kimberly S. Reece ${ }^{1}$, \\ Eugene M. Burreson ${ }^{1}$, Ryan B. Carnegie ${ }^{1, *}$ \\ ${ }^{1}$ Virginia Institute of Marine Science, College of William \& Mary, PO Box 1346, Gloucester Point, Virginia 23062, USA \\ ${ }^{2}$ Cawthron Institute, Private Bag 2, Nelson 7042, New Zealand \\ ${ }^{3} 73$, rue de la Fée au Bois, 17450 Fouras, France \\ ${ }^{4}$ Laboratorio de Histopatología de Moluscos, Instituto de Biología Marina y Pesquera ‘Alte Storni', Güemes 1030, CC: 104, \\ San Antonio Oeste 8520 (Rio Negro), Argentina \\ ${ }^{5}$ California Department of Fish and Game, Bodega Marine Laboratory, PO Box 247, Bodega Bay, California 94923, USA \\ ${ }^{6}$ Auckland Museum, The Domain, Private Bag 92018, Auckland 1142, New Zealand \\ ${ }^{7}$ Present address: Grice Marine Laboratory, College of Charleston, 205 Fort Johnson Road, Charleston, \\ South Carolina 29412, USA
}

\begin{abstract}
The genus Bonamia (Haplosporidia) includes economically significant oyster parasites. Described species were thought to have fairly circumscribed host and geographic ranges: $B$. ostreae infecting Ostrea edulis in Europe and North America, B. exitiosa infecting O. chilensis in New Zealand, and B. roughleyi infecting Saccostrea glomerata in Australia. The discovery of $B$. exitiosa-like parasites in new locations and the observation of a novel species, $B$. perspora, in noncommercial $O$. stentina altered this perception and prompted our wider evaluation of the global diversity of Bonamia parasites. Samples of 13 oyster species from 21 locations were screened for Bonamia spp. by PCR, and small subunit and internal transcribed spacer regions of Bonamia sp. ribosomal DNA were sequenced from PCR-positive individuals. Infections were confirmed histologically. Phylogenetic analyses using parsimony and Bayesian methods revealed one species, $B$. exitiosa, to be widely distributed, infecting 7 oyster species from Australia, New Zealand, Argentina, eastern and western USA, and Tunisia. More limited host and geographic distributions of $B$. ostreae and B. perspora were confirmed, but nothing genetically identifiable as $B$. roughleyi was found in Australia or elsewhere. Newly discovered diversity included a Bonamia sp. in Dendostrea sandvicensis from Hawaii, USA, that is basal to the other Bonamia species and a Bonamia sp. in $O$. edulis from Tomales Bay, California, USA, that is closely related to both $B$. exitiosa and the previously observed Bonamia sp. from O. chilensis in Chile.
\end{abstract}

KEY WORDS: Bonamia $\cdot$ Haplosporidia $\cdot$ Phylogeny

Resale or republication not permitted without written consent of the publisher

\section{INTRODUCTION}

Bonamia species are protozoan parasites of oysters in the phylum Haplosporidia whose characteristic cell form is a 2-3 $\mu \mathrm{m}$ uninucleate 'microcell' (Pichot et al. 1980, Carnegie \& Cochennec-Laureau 2004). There are 3 described species, from 3 different oyster hosts: Bonamia ostreae (Pichot et al. 1980) in Ostrea edulis L.; B. exitiosa (Hine et al. 2001) in $O$. chilensis Philippi, 1845; and B. perspora (Carnegie 
et al. 2006) in O. stentina Payraudeau, 1826 (formerly Ostreola equestris Say, 1834). A fourth parasite, Mikrocytos roughleyi (Farley et al. 1988) from Saccostrea glomerata Gould 1850, was reassigned to the genus Bonamia based on molecular analyses (Cochennec-Laureau et al. 2003), but it is not clear whether the Bonamia sp. detected in S. glomerata is distinct from B. exitiosa (Hill et al. 2010). A recent analysis argued that the parasite genetically identified as $B$. roughleyi was actually a mis-identified B. exitiosa (Carnegie et al. 2014).

Questions regarding the diversity and geographic distribution of Bonamia species began to emerge in conjunction with new discoveries of the geographic and host ranges of these parasites. Prior to 2004, Bonamia parasites were viewed as having fairly circumscribed host and geographic distributions $-B$. ostreae in $O$. edulis in the temperate Northern Hemisphere, B. exitiosa in $O$. chilensis in southern New Zealand, and the little studied $B$. roughleyi restricted to New South Wales, Australia. However, this perspective began to change when Burreson et al. (2004) found a $B$. exitiosa-like species infecting experimentally deployed Crassostrea ariakensis Fujita 1913 in Bogue Sound, North Carolina, USA. This parasite was subsequently observed infecting native oyster $O$. stentina (=Ostreola equestris; Shilts et al. 2007) in North Carolina, a species that was additionally found to host the novel parasite described as $B$. perspora (Carnegie et al. 2006, Hill et al. 2010). Additional observations of Bonamia parasites were made in $O$. chilensis from Chile (Campalans et al. 2000), $O$. puelchana from Argentina (Kroeck \& Montes 2005), O. angasi from Australia (Corbeil et al. 2006), $O$. edulis from Spain (Abollo et al. 2008) and Italy (Narcisi et al. 2010), and O. stentina from the Mediterranean (Hill et al. 2010), but whether or not these were distinct from a described Bonamia species, particularly $B$. exitiosa, was not certain.

A phylogeographic study of Bonamia parasites is important given the ecological and economic destruction these parasites can cause in oyster hosts. $B$. ostreae, for example, contributed greatly to the collapse of $O$. edulis populations and fisheries in Europe (Grizel et al. 1988), and B. exitiosa has devastated $O$. chilensis populations in New Zealand (Hine et al. 2001). The objective of this study was to assess the global distribution of Bonamia parasites by collecting potential oyster hosts from around the world to better understand the geographic and host ranges and the genetic diversity of these parasites. Separate phylogenies were constructed based on the small subunit ribosomal RNA gene (SSU rDNA) and internal tran- scribed spacer (ITS) region rDNA (defined as ITS-1 rDNA, the 5.8S rRNA gene, and ITS-2 rDNA and hereafter referred to as ITS rDNA) to better understand the host and geographic boundaries and the evolutionary relationships of Bonamia species that were found in several new hosts and locations. Additionally, given the morphological similarities of all Bonamia parasites, we used in situ hybridization of archival materials to re-examine microcell observations from the pre-molecular era and revisit previous conclusions regarding the geographic distribution of Bonamia parasites.

\section{MATERIALS AND METHODS}

\section{Sample collection and processing}

Samples of 11 oyster species were obtained from 21 locations around the world (Table 1). Most oysters were collected from natural habitats. However, samples of Crassostrea ariakensis from Florida, USA, were hatchery-produced by the Virginia Institute of Marine Science and experimentally deployed; Ostrea denselamellosa from the Okayama Prefecture, Japan, were cultured as part of a restoration program; and O. angasi from Australia, Saccostrea glomerata from Australia, and one sample of O. chilensis from Chile were obtained from commercial aquaculture. With the exception of the $C$. ariakensis samples, the hatchery sources of the cultured oysters are not known. Oysters were shucked, and small pieces of gill and mantle tissue $\left(\sim 3-5 \mathrm{~mm}^{3}\right)$ were either preserved individually in $95 \%$ ethanol or placed directly in lysis solution (QIAamp DNA Kit, QIAGEN) for molecular analyses. The only exceptions were $O$. edulis and 2004 O. lurida tissue samples collected from California, USA. Tissues from $O$. lurida individuals were stored at $-80^{\circ} \mathrm{C}$ in pools of 3 or 4 oysters per tube, and then preserved in $100 \%$ ethanol for shipping. The California $O$. edulis samples were preserved in $95 \%$ ethanol, but again pooled: 14 pools of 4 individuals, and 1 pool of 2 individuals in 1 sample. All instruments used for dissection were sterilized with $95 \%$ ethanol and flamed between each sample. Remaining tissues, including gill, mantle, and visceral mass, were fixed in Davidson's fixative (Shaw \& Battle 1957) for standard histopathology. For Isognomon sp. from Florida, O. edulis from the Netherlands, O. chilensis from Chile, and the 2006 Dendostrea sandvicensis samples, tissues were collected for molecular analyses only. 
Table 1. Collection information and Bonamia sp. PCR prevalence data. PCR primers Bon-319F + Bon-524R were used for amplifications unless otherwise noted. n/a: not applicable

\begin{tabular}{|c|c|c|c|c|}
\hline Oyster species & Location & $\begin{array}{l}\text { Collection date } \\
(\mathrm{mo} / \mathrm{d} / \mathrm{yr})\end{array}$ & $\begin{array}{l}\text { Sample } \\
\text { size }\end{array}$ & $\begin{array}{c}\text { Bonamia spp. } \\
\text { PCR prevalence (\%) }\end{array}$ \\
\hline Crassostrea ariakensis & Fort Pierce, Florida, USA & $4 / 16 / 2007$ & 17 & $6 / 17(35.3 \%)$ \\
\hline Crassostrea ariakensis & Fort Pierce, Florida, USA & $6 / 14 / 2007$ & 19 & 8/19 (42.1\%) \\
\hline Isognomon sp. & Long Key, Florida, USA ${ }^{a}$ & $7 / 10 / 2009$ & 30 & $0 / 30(0 \%)$ \\
\hline Ostrea stentina & Old House Creek, South Carolina, USA & $4 / 12 / 2006$ & 55 & $2 / 55(3.6 \%)^{\mathrm{c}}$ \\
\hline Ostrea stentina & Wilmington, North Carolina, USA & $6 / 22 / 2005$ & 200 & $8 / 200(4.0 \%)^{\mathrm{d}}$ \\
\hline Ostrea stentina & Morehead City Port, North Carolina, USA & $8 / 1 / 2005$ & 150 & $3 / 150(2.0 \%)^{\mathrm{e}}$ \\
\hline Ostrea puelchana & San Antonio Bay, Argentina & $3 / 22 / 2005$ & 57 & $6 / 57(10.5 \%)^{\mathrm{c}}$ \\
\hline Ostrea stentina & San Antonio Bay, Argentina & $04 / 2007$ & 3 & $3 / 3\left(n / a^{f}\right)$ \\
\hline Ostrea lurida & Lemmens Inlet, British Columbia, Canada & $4 / 01 / 2005$ & 25 & $0 / 25(0 \%)$ \\
\hline Ostrea lurida & Drakes Estero, California, USA & $7 / 7 / 2004$ & $15^{\mathrm{b}}$ & $0 / 15^{\mathrm{b}}(0 \%)$ \\
\hline Ostrea lurida & Elkhorn Slough, California, USA & $5 / 27 / 2004$ & $15^{\mathrm{b}}$ & $13 / 15^{\mathrm{b}}(21.7-86.7 \%)$ \\
\hline Ostrea lurida & Elkhorn Slough, California, USA & 09/17/2009 & 60 & $53 / 60(88.3 \%)$ \\
\hline Ostrea edulis & Tomales Bay, California, USA & $10 / 7 / 2005$ & $32^{\mathrm{b}}$ & $21 / 32^{\mathrm{b}}(20.7-82.0 \%)$ \\
\hline Dendostrea sandvicensis & Kaneohe Bay, Hawaii, USA ${ }^{a}$ & 06/2006 & 120 & $79 / 120(65.8 \%)$ \\
\hline Dendostrea sandvicensis & Kaneohe Bay, Hawaii, USA & 10/18-20/2007 & 60 & $42 / 60(70.0 \%)$ \\
\hline Ostrea denselamellosa & Seto Inland Sea, Okayama Prefecture, Japan & $7 / 13 / 2009$ & 40 & $0 / 40(0 \%)$ \\
\hline Ostrea angasi & Pambula River, New South Wales, Australia & $11 / 2006$ & 42 & $1 / 42(2.4 \%)$ \\
\hline Saccostrea glomerata & Georges River, New South Wales, Australia & $08 / 2007$ & 200 & $1 / 200(0.5 \%)$ \\
\hline Ostrea stentina & Tamaki Estuary, Glendowie, New Zealand & $8 / 14 / 2007$ & 44 & $4 / 44(9.1 \%)$ \\
\hline Ostrea stentina & Karaka Bay, Tamaki Estuary, Auckland, New Zealand & $3 / 13 / 2009$ & 90 & $5 / 90(5.6 \%)$ \\
\hline Ostrea chilensis & Foveaux Strait, New Zealand & $01 \& 03 / 2005$ & 5 & $4 / 5\left(\mathrm{n} / \mathrm{a}^{\mathrm{f}}\right)$ \\
\hline Ostrea chilensis & Foveaux Strait, New Zealand & 06/13/2004 & 40 & $2 / 40(5.0 \%)$ \\
\hline Saccostrea glomerata & Whangarei Harbour, Northland, New Zealand & $3 / 2 / 2008$ & 50 & $0 / 50(0 \%)$ \\
\hline Saccostrea glomerata & Whangarei Harbour, Northland, New Zealand & $5 / 1 / 2009$ & 60 & $0 / 60(0 \%)$ \\
\hline Ostrea chilensis & Chiloe Island, Chile ${ }^{\mathrm{a}}$ & $12 / 2003$ & 1 & $1 / 1\left(n / a^{f}\right)$ \\
\hline Ostrea chilensis & Chiloe Island, Chile ${ }^{a}$ & $10 / 2003$ & 32 & $6 / 32(18.8 \%)$ \\
\hline Ostrea stentina & Hammamet, Tunisia & $06 / 2007$ & 85 & $8 / 85(10.6 \%)$ \\
\hline Ostrea edulis & Lake Grevelingen, The Netherlands ${ }^{\mathrm{a}}$ & $05 / 2008$ & 1 & $1 / 1\left(\mathrm{n} / \mathrm{a}^{\mathrm{f}}\right)$ \\
\hline
\end{tabular}

\section{DNA extraction and diagnostic PCR}

Genomic DNA from each oyster sample was extracted using a QIAamp DNA Kit. DNA was eluted in 100-225 $\mu \mathrm{l}$ of elution buffer and stored at $4^{\circ} \mathrm{C}$. For the pooled $O$. edulis samples from California, each pool was divided into 2 individuals per extraction (except one pool that had larger pieces of tissue, for which the 4 individuals were divided into 4 separate extractions). This was done in order to obtain a better estimate of prevalence.

After each extraction, DNA was quantified using a GeneQuant pro spectrophotometer (Amersham Biosciences). Oysters were screened for Bonamia spp. DNA using either generic PCR primers Bon-319F and Bon-524R (Hill et al. 2010), which target a 206 bp portion of Bonamia spp. SSU rDNA, or generic primers $\mathrm{C}_{\mathrm{F}}$ and $\mathrm{C}_{\mathrm{R}}$ (Carnegie et al. 2000), which amplify a 760 bp portion of Bonamia spp. SSU rDNA. (The approximate primer binding sites for this and all other primer pairs used in this study are presented in Fig. 1.) For the Bon-319F + Bon-524R PCR, a $25 \mu$ total volume reaction contained 1× PCR buffer (Applied Biosystems), $1.5 \mathrm{mM} \mathrm{MgCl} \mathrm{Mg}_{2}, 0.2 \mathrm{mM}$ dNTPs, $0.4 \mu \mathrm{g} \mathrm{ul}^{-1}$ bovine serum albumin (BSA), $0.25 \mu \mathrm{M}$ primer mix, 0.024 units $\mu^{-1}$ AmpliTaq DNA polymerase (Applied Biosystems), and 200-250 ng (=0.5-1.6 $\mu \mathrm{l})$ template DNA. A $4 \mathrm{~min}$ initial denaturation at $94^{\circ} \mathrm{C}$ was followed by 35 cycles of denaturation at $94^{\circ} \mathrm{C}$ for $30 \mathrm{~s}$, annealing at $60^{\circ} \mathrm{C}$ for $30 \mathrm{~s}$, and extension at $72^{\circ} \mathrm{C}$ for $1 \mathrm{~min}$, and then by a final extension at $72^{\circ} \mathrm{C}$ for $7 \mathrm{~min}$. Products were electrophoresed on $2.5 \%$ agarose gels (100 V, $30 \mathrm{~min})$, subsequently stained with ethidium bromide, and visualized under a UV light.

The $25 \mu \mathrm{l} \mathrm{C}_{\mathrm{F}}+\mathrm{C}_{\mathrm{R}}$ reaction contained the same reagents and concentrations, but thermal cycling 


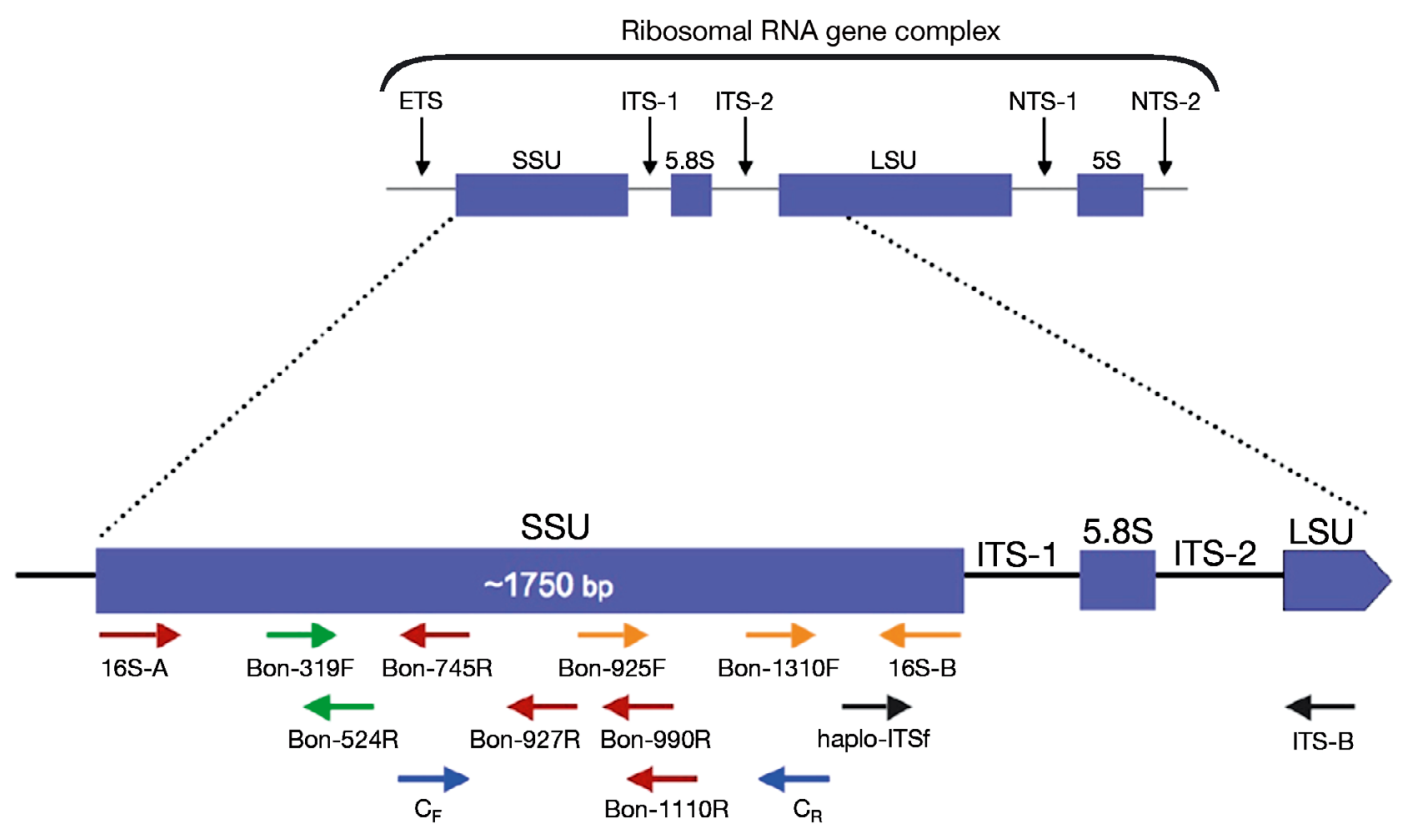

Fig. 1. Schematic representation of ribosomal RNA gene complex-targeted PCR assays used in this study. Forward primers (F) were paired with reverse primers $(\mathrm{R})$, with colors indicating which primers were used in combination. ITS: internal transcribed spacer; SSU: small subunit; LSU: large subunit

was performed as described in Carnegie et al. (2000): a 4 min initial denaturation at $94^{\circ} \mathrm{C}$ was followed by 35 cycles of denaturation at $94^{\circ} \mathrm{C}$ for $1 \mathrm{~min}$, annealing at $59^{\circ} \mathrm{C}$ for $1 \mathrm{~min}$, and extension at $72^{\circ} \mathrm{C}$ for $1 \mathrm{~min}$, and then by a final extension at $72^{\circ} \mathrm{C}$ for $10 \mathrm{~min}$. These products were electrophoresed on $2 \%$ agarose gels (100 V, $30 \mathrm{~min})$, stained with ethidium bromide, and visualized under UV light.

\section{SSU rDNA sequencing}

PCR products from infected oysters were used to generate Bonamia spp. SSU rDNA sequence. One to 3 PCR-positive oysters, 2 to 3 primer sets, and 3 to 9 clones per primer set were used to obtain complete SSU rDNA sequences. In order to generate sequence for the entire SSU rDNA region ( 1750 bp), multiple PCR amplifications had to be performed. Several primer pairs were tested, and the pair that yielded a single amplicon of appropriate size was used for subsequent cloning reactions. In order to amplify the $5^{\prime}$ end of Bonamia spp. SSU rDNA region, a reverse Bonamia-generic primer (Bon-745R, Bon-927R, Bon990R, Bon-1110R, or Bon-1050R) was paired with primer 16S-A (Medlin et al. 1988), a universal primer that amplifies eukaryotic SSU rDNA (Table 2). The 3' end of Bonamia spp. SSU was generated using a for- ward Bonamia-generic primer (Bon-925F or Bon1310F) paired with primer 16S-B (Medlin et al. 1988) (Table 2). In most cases, a third PCR had to be performed in order to complete the SSU rDNA region. Either $\mathrm{C}_{\mathrm{F}}+\mathrm{C}_{\mathrm{R}}$ or Bon-319F + Bon-990R primer pairs were used to generate sequencing data for the gap (Table 2). For the Bonamia sp. from D. sandvicensis in Hawaii, a new primer, HIBon-620F, was designed using MacVector 8.0 (Oxford Molecular) in order to obtain the middle portion of the SSU rDNA sequence, and was paired with Bon-1110R (White 2008) (Table 2). For each PCR, a $25 \mu \mathrm{l}$ total reaction volume contained the same reagents at the same concentrations as the Bon-319F + Bon-524R PCR described above. A 4 min initial denaturation was followed by 35 cycles of denaturation at $94^{\circ} \mathrm{C}$ for $45 \mathrm{~s}$, annealing at $54-58^{\circ} \mathrm{C}$ for $45 \mathrm{~s}$, extension at $72^{\circ} \mathrm{C}$ for 1 min (for products $<\sim 800$ $\mathrm{bp}$ ) or $1.5 \mathrm{~min}$ (for products $>\sim 800 \mathrm{bp}$ ), and then by a final extension at $72^{\circ} \mathrm{C}$ for 6 min (except for the $\mathrm{C}_{\mathrm{F}}+$ $\mathrm{C}_{\mathrm{R}}$ PCR, which was performed as described above). The selected amplification products from triplicate PCR reactions were pooled and purified using a QIAquick PCR purification kit (QIAGEN).

The reactions to obtain the Bonamia sp. SSU rDNA found in $O$. edulis from California differed from the above descriptions in that a $25 \mu \mathrm{l}$ total reaction volume contained 1× PCR buffer (Invitrogen), $2 \mathrm{mM}$ $\mathrm{MgCl}_{2}, 0.2 \mathrm{mM}$ dNTPs, $0.25 \mu \mathrm{M}$ forward primer, 
Table 2. Bonamia spp. sequences of PCR primers and in situ hybridization probes. Binding site ranges defined using B. exitiosa in Ostrea chilensis from New Zealand (GenBank accession no. JF495410) as the target sequence unless noted. ITS: internal transcribed spacer; SSU: small subunit; ISH: in situ hybridization; FISH: fluorescent in situ hybridization; n/a: not applicable

\begin{tabular}{|c|c|c|c|c|}
\hline Name & Sequence $\left(5^{\prime}-3^{\prime}\right)$ & $\begin{array}{l}\text { Bonamia sp. } \\
\text { SU binding sit }\end{array}$ & Use & Reference \\
\hline $\mathrm{C}_{\mathrm{F}}$ & CGG GGG CAT AAT TCA GGA AC & $663-682^{\mathrm{a}}$ & Bonamia spp. PCR; SSU seq. & Carnegie et al. (2000) \\
\hline $\mathrm{C}_{\mathrm{R}}$ & CCA TCT GCT GGA GAC ACA G & $1401-1383$ & Bonamia spp. PCR; SSU seq. & Carnegie et al. (2000) \\
\hline Bon-319F & TTT GAC GGG TAA CGG GGA ATG CG & $301-323$ & Bonamia spp. PCR; SSU seq. & Hill et al. (2010) \\
\hline Bon-524R & CTT GCC CTC CGC TGG AAT TC & $505-486$ & Bonamia spp. PCR & Hill et al. (2010) \\
\hline Bon-745R & CTA ATG CAT TCA GGC GCG AG & $754-735$ & Bonamia spp. PCR; SSU seq. & Carnegie et al. (2006) \\
\hline Bon-925F & ATT CCG GTG AGA CTA ACT TAT G & $885-906$ & Bonamia spp. PCR; SSU seq. & White (2008) \\
\hline Bon-927R & CAT AAG TTA GTC TCA CCG GAA TT & $906-884$ & Bonamia spp. PCR; SSU seq. & This study \\
\hline Bon-990R & CTT AGT CGA CAT CGT TTA TGG TTG GG & $1011-986$ & Bonamia spp. PCR; SSU seq. & White (2008) \\
\hline Bon-1110R & CCT TTA AGT TTC ACT CTT GCG AG & $1102-1080$ & Bonamia spp. PCR; SSU seq. & White (2008) \\
\hline Bon-1310F & GAG ACC CCA CCC ATC TAA C & $1288-1306$ & Bonamia spp. PCR; SSU seq. & Carnegie et al. (2006) \\
\hline HIBon-620F & CGG CAC GCA CGT AAG TGG AG & $620-639^{\mathrm{b}}$ & $\begin{array}{c}\text { Hawaiian Bonamia PCR; } \\
\text { SSU seq. }\end{array}$ & This study \\
\hline $16 \mathrm{~S}-\mathrm{A}$ & AAC CTG GTT GAT CCT GCC AGT & $5^{\prime}$ end SSU & Universal SSU PCR; seq. & Medlin et al. (1988) \\
\hline $16 \mathrm{~S}-\mathrm{B}$ & GAT CCT TCC GCA GGT TCA CCT AC & $3^{\prime}$ end SSU & Universal SSU PCR; seq. & Medlin et al. (1988) \\
\hline haplo-ITSf & GGG ATA GAT GAT TGC AAT TRT TC & $1529-1551$ & Haplosporidia ${ }^{\mathrm{C}} \mathrm{PCR}_{i}$ ITS seq. & Hill et al. (2010) \\
\hline ITS-B & TAT GCT TAA ATT CAG CGG GT & 5' end LSU & Universal ITS PCR; ITS seq. & Goggin (1994) \\
\hline 16Sar & CGC CTG TTT ATC AAA AAC AT & $\mathrm{n} / \mathrm{a}$ & $\begin{array}{l}\text { Universal mt16S PCR; } \\
\text { host mtDNA seq }\end{array}$ & Kessing et al. (1989) \\
\hline 16Sbr & CCG GTC TGA ACT CAG ATC ACG T & $\mathrm{n} / \mathrm{a}$ & $\begin{array}{l}\text { Universal mt16S PCR } \\
\text { host mtDNA seq }\end{array}$ & Kessing et al. (1989) \\
\hline CaBon166 & CGA GCA GGG TTT GTC ACG TAT & $166-146$ & B. exitiosa dig-ISH & Hill et al. (2010) \\
\hline CaBon461 & TTC CGA ATA GGC AAC CGA AG & $461-442$ & B. exitiosa dig-ISH & Hill et al. (2010) \\
\hline CaBon1704 & CAA AGC TTC TAA GAA CGC GCC & $1704-1684$ & B. exitiosa dig-ISH & Hill et al. (2010) \\
\hline Bost171 & CCG CCG AGG CAG GGT TTG T & $187-169^{\mathrm{a}}$ & B. ostreae dig-ISH & Present study \\
\hline BON1490 & GTC AAG CCG GGT CAA ACT CGT TG & $1473-1495$ & Bonamia dig-ISH & Present study \\
\hline HIBon-167 & CTA ATA TGC ACA GCC GCC AG & $186-167^{\mathrm{b}}$ & Hawaiian Bonamia FISH & Present study \\
\hline HIBon-634 & CGA TTA TGG CCT CTC TCC AC & $653-634^{\mathrm{b}}$ & Hawaiian Bonamia-FISH & Present study \\
\hline Oe-309 & TCA TGC TCC CTC TCC GG & $\mathrm{n} / \mathrm{a}$ & Universal SSU probe & $\begin{array}{l}\text { Cáceres-Martínez } \\
\text { et al. (2012) }\end{array}$ \\
\hline
\end{tabular}

$0.25 \mu \mathrm{M}$ reverse primer, 0.05 units $\mu^{-1}$ Platinum Taq DNA polymerase (Invitrogen), and 200-250 ng template DNA. The thermal cycling program was as stated above. Duplicate reactions were individually purified; amplification products were not pooled as for other samples.

Purified PCR products were cloned into the plasmid vector pCR4-TOPO using the TOPO TA Cloning kit (Invitrogen), and then transformed into One Shot TOP10 competent Escherichia coli cells (Invitrogen). Colonies were screened either using phenol/chloroform/isoamyl-alcohol (PCI) extractions or by PCR using M13 vector primers. Clones with inserts of desired size were cultured and plasmids were extracted using the QIAprep Spin Miniprep Kit protocol (QIAGEN), and sequenced on either a LI-COR 4200L or a 16-capillary 3130xl Genetic Analyzer (Applied Biosystems).

\section{ITS region rDNA sequencing}

Bonamia sp. ITS rDNA region sequences were characterized for oysters that initially tested positive for a Bonamia sp. using SSU rDNA-based assays above. One to 7 Bonamia-positive oysters per species were characterized by ITS rDNA sequencing. The primers HaploITSf (Hill et al. 2010) and ITS-B (= reverse primer D; Goggin 1994) were used (Table 2). This primer pair amplifies $\sim 220 \mathrm{bp}$ of the $3^{\prime}$ end of the SSU rRNA gene, the complete ITS-1, 5.8S gene, and ITS-2 region rDNA, and a short fragment of the large subunit (LSU) rDNA of most haplosporidians, yielding a product of approximately $750 \mathrm{bp}$ from Bonamia spp. Initially, PCR reactions were performed in triplicate and pooled as described above for cloning and SSU rDNA sequencing. These reactions were carried out using Applied Biosystems reagents at the same con- 
centrations as described above for the Bon-319F + Bon-524R PCR. After June 2008, however, duplicate reactions were performed on each individual or pool of individuals, with each reaction individually cloned, sequenced, and compared. The objective of this change in protocol was to allow the detection of more rare variant sequences. A $25 \mu \mathrm{l}$ total reaction contained 1× PCR Buffer (Invitrogen), 2-2.5 mM MgCl 2 ,

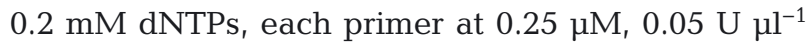
Platinum Taq DNA polymerase (Invitrogen), and 200-250 ng ( $=0.5-1.6 \mu \mathrm{l})$ template DNA. Regardless of reagents used, a 7 min initial denaturation was followed by 35 cycles of denaturation at $95^{\circ} \mathrm{C}$ for $1 \mathrm{~min}$, annealing between 55 and $61^{\circ} \mathrm{C}$ for $1 \mathrm{~min}$, and extension at $72^{\circ} \mathrm{C}$ for $1.5 \mathrm{~min}$, and then by a final extension at $72^{\circ} \mathrm{C}$ for $7 \mathrm{~min}$. These products were purified, cloned, transformed, screened, and sequenced as in the above description of SSU rDNA sequencing. One to 29 clones per individual host were sequenced.

\section{Oyster mt16S rDNA sequencing}

All oysters were presumptively identified based on morphological characteristics and sample locations. However, universal primers 16Sar and 16Sbr (Kessing et al. 1989) (Table 2) were used to amplify a portion of the mitochondrial 16S (mt16S) rRNA gene of Bonamiapositive host species to confirm oyster identity of $O$. stentina (=O. aupouria; Shilts et al. 2007) from New Zealand, $O$. lurida and $O$. edulis from California, $O$. stentina from Argentina, $O$. stentina from Tunisia, and D. sandvicensis from Hawaii. A $25 \mu \mathrm{l}$ total reaction contained 1× PCR Buffer (Applied Biosystems), $1.5 \mathrm{mM}$ $\mathrm{MgCl}_{2}, 0.2 \mathrm{mM}$ dNTPs, $0.4 \mu \mathrm{g} \mathrm{l}^{-1}$ BSA, $0.20 \mu \mathrm{M}$ primer mix, 0.024 units $\mu l^{-1}$ Ampli Taq DNA polymerase (Applied Biosystems), and 200-250 ng (= 0.5-2.5 $\mathrm{\mu l})$ template DNA. Reaction conditions were modified from Kirkendale et al. (2004): initial denaturation at $95^{\circ} \mathrm{C}$ for 4 min was followed by 38 cycles of denaturation at $95^{\circ} \mathrm{C}$ for $1 \mathrm{~min}$, annealing at $52^{\circ} \mathrm{C}$ for $1 \mathrm{~min}$, and extension at $72^{\circ} \mathrm{C}$ for $2 \mathrm{~min}$, and by a final extension at $72^{\circ} \mathrm{C}$ for $7 \mathrm{~min}$. Products were electrophoresed and visualized as above. PCR products were purified using a QIAquick PCR Purification Kit (QIAGEN) and quantified using either a DyNA Quant 200 fluorometer (Hoefer Pharmacia Biotech) or a NanoDrop 2000 (Thermo Fisher Scientific) as per the manufacturers' instructions. Three to 10 nanograms of the purified PCR product was then added to the reagents from a BigDye ${ }^{\circledR}$ Terminator v3.1 cycle sequencing kit (using manufacturer's instructions, modified for $5 \mu \mathrm{l}$ reactions) and the 16Sar and 16Sbr primers (Kessing et al. 1989).
Reactions were then cleaned, precipitated, and sequenced as above. Resulting sequences were compared with sequences in the National Center for Biotechnology Information (NCBI) GenBank database by using the Basic Local Alignment Search Tool (BLAST; Altschul et al. 1997).

\section{Sequence alignments and molecular phylogenetics}

Newly generated SSU rDNA Bonamia spp. sequences from C. ariakensis from Florida, O. stentina from Argentina, O. edulis and O. lurida from California, $D$. sandvicensis from Hawaii, S. glomerata from Australia, O. stentina and $O$. chilensis from New Zealand, and $O$. edulis from The Netherlands were aligned with published SSU rDNA sequences. These included B. ostreae (GenBank accession numbers AF262995 and AF192759), B. exitiosa (AF337563), B. roughleyi (AF508801), and B. perspora (DQ356000); the Bonamia spp. from $O$. stentina from Tunisia (GQ385242), C. ariakensis from North Carolina (AY542903), O. edulis from Spain (EU016528) and Italy (EU598800, EU598801), O. angasi from Australia (DQ312295, JF495408), O. chilensis from Chile (AY860060, GQ366703), and O. puelchana from Argentina (JF495409); and outgroup species Minchinia tapetis (AY449710), M. teredinis (U20319), M. chitonis (AY449711), and M. mercenariae (FJ518816). Minchinia spp. were chosen as an outgroup because Minchinia is sister to Bonamia in the haplosporidian phylogeny (Reece et al. 2004).

Bonamia spp. ITS rDNA sequences amplified from C. ariakensis from Florida, O. angasi and S. glomerata from Australia, O. stentina and $O$. chilensis from New Zealand, $O$. chilensis from Chile, O. lurida and $O$. edulis from California, O. edulis from the Netherlands, O. stentina and O. puelchana from Argentina, $O$. stentina from North and South Carolina and Tunisia, and $D$. sandvicensis from Hawaii were aligned with GenBank-deposited Bonamia spp. ITS rDNA sequences from $C$. ariakensis from North Carolina, O. puelchana from Argentina, O. angasi from Australia, and $O$. chilensis from New Zealand and Chile, with $B$. ostreae sequences from $O$. edulis from Maine, and with $B$. perspora sequences from $O$. stentina from North Carolina. GenBank accession numbers can be found in Table 3 . All sequences were bidirectional except some of the GenBank-deposited Bonamia sp. sequences from $O$. angasi (EU780686EU780692). Both the SSU and the ITS rDNA alignments were carried out using the automatic setting in MAFFT v. 6 (Katoh \& Toh 2008). 


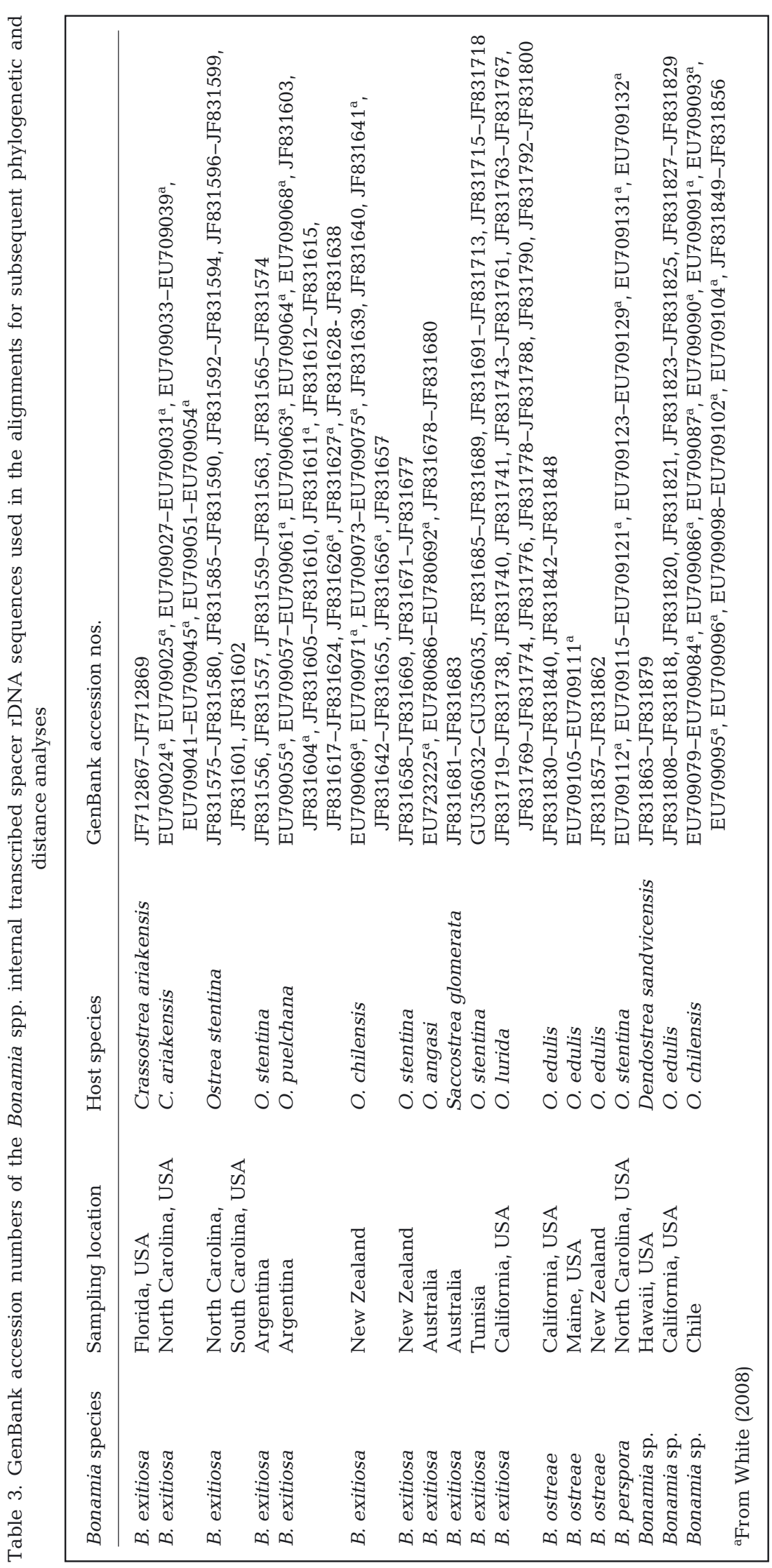

For the ITS rDNA distance analyses, the SSU rDNA portion of the amplicon produced by the HaploITSf + ITS-B primer set was removed from the alignment. Incomplete sequences were also removed from the above ITS rDNA alignment so that all sequences spanned identical regions. The data set was then realigned using MAFFT v. 6, again on the automatic setting (Katoh \& Toh 2008).

Parsimony analysis of SSU rDNA sequence data was conducted using PAUP* 4.0b10 (Swofford 2002). One thousand bootstrap replicates with 100 random additions were performed. Gaps were treated as missing. Parsimony analysis of ITS region sequence data was performed using TNT v. 1.1 (Tree analysis using New Technology; Goloboff et al. 2008). A new technology search was completed with 100 bootstrap replicates and 10 random additions. A $50 \%$ majority rule unrooted consensus tree was generated using PAUP* $4.0 \mathrm{~b} 10$.

Bayesian inference analyses of SSU and ITS rDNA sequence data were conducted using MrBayes v. 3.1.2 (Ronquist \& Huelsenbeck 2003). MrModeltest v. 2.3 was used to determine the best model for each data set. Are We There Yet? (AWTY; Wilgenbusch et al. 2004) was used to determine whether stationarity had been reached for the SSU rDNA dataset. Fifty percent majority rule consensus trees were generated using $\mathrm{PAUP}^{*} 4.0$ b10 (Swofford 2002).

\section{Distance analyses}

Distance analyses were performed using MEGA v. 4 (Tamura et al. 2007). For the Bonamia spp. SSU rDNA data set, uncorrected p-distances were calculated between the different Bonamia clades that were indicated by the parsimony 
and Bayesian analyses. Gaps and missing data were only eliminated in pairwise sequence comparisons (pairwise deletion option). Standard error estimates were determined by a bootstrap procedure (1000 replicates). For the ITS rDNA data set, uncorrected pdistances were calculated between and within each Bonamia clade, again as indicated by the parsimony and Bayesian analyses of the ITS rDNA sequences. Again, the pairwise deletion option was used and standard error estimates were determined by a bootstrap procedure (1000 replicates).

\section{In situ hybridization of contemporary samples}

Standard, chromogenic in situ hybridization (ISH) assays specific for $B$. ostreae and $B$. exitiosa were performed with digoxigenin-labeled anti-sense probes on tissue sections of $C$. ariakensis from Florida, $O$. stentina from New Zealand, and $O$. lurida and $O$. edulis from California that were PCR-positive for a Bonamia sp. The $B$. exitiosa specific ISH used a cocktail of 3 probes, CaBon461 + CaBon166 + CaBon1704, at $2 \mathrm{ng} \mathrm{ll}^{-1}$ each (Hill et al. 2010) (Table 2) and the $B$. ostreae-specific assay used a single probe, Bost171,

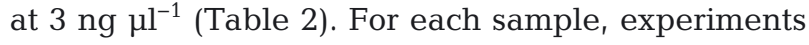
included the following treatments: a no-probe control (25 $\mu$ l hybridization buffer only), a positive control (B. exitiosa-infected C. virginica or C. ariakensis from North Carolina, USA, for the $B$. exitiosa-specific assays; and B. ostreae-infected $O$. edulis from Maine, USA, for the $B$. ostreae-specific assays), and a standard experimental treatment using CaBon probes (Hill et al. 2010) and/or Bost171 (Table 2).

Tissue sections for ISH were processed as described previously (Stokes \& Burreson 1995) with a few modifications as follows. Protease treatment was changed to $50 \mu \mathrm{g} \mathrm{ml} \mathrm{m}^{-1}$ Proteinase $\mathrm{K}$ in PBS for $18 \mathrm{~min}$ at $37^{\circ} \mathrm{C}$. After hybridization, the washes in $0.5 \times \operatorname{SSC}(2 \times 10 \mathrm{~min})$ were at $42^{\circ} \mathrm{C}$ for the Bost171 probe and $45^{\circ} \mathrm{C}$ for the CaBon probe cocktail. Slides were counterstained with Bismarck Brown Y after color development as in Stokes \& Burreson (2001) and were examined on an Olympus BX51 light microscope.

A fluorescent in situ hybridization (FISH) assay was used to visualize the Bonamia sp. found in D. sandvicensis. Anti-sense probes HIBon-167 and HIBon-634 (Table 2) tagged with Alexa Fluor 488 labels (Invitrogen) were designed in MacVector 8.0 to specifically target this parasite's SSU rRNA. The assay was optimized and tested for specificity against available Bonamia species (B. exitiosa, B. perspora, and $B$. ostreae). Slides were treated with HIBon-167 + HIBon-634 (each at $10 \mathrm{ng} \mathrm{ul}^{-1}$ ), a no-probe control (hybridization buffer only), and a positive control (Oe-309 at $10 \mathrm{ng}^{-1} \mathrm{l}^{-1}$ ) for ensuring general probe accessibility to oyster tissue (Table 2). The FISH assay was performed as in Carnegie et al. (2006), except a descending ethanol series was used for rehydration instead of a descending isopropanol series. As an added component to the FISH experiment, fluorescently labeled $B$. exitiosa-specific CaBon probes were hybridized to $B$. exitiosa-infected $C$. ariakensis and to the Bonamia sp.-infected $D$. sandvicensis individual, with experimental conditions as above. Slides were evaluated on an Olympus Provis epifluorescence microscope equipped with a red-green dual bandpass filter.

\section{In situ hybridization of archival material}

Paraffin-embedded oyster tissue was re-cut from archival blocks in which microcells were originally identified by Farley et al. (1988) using histology. These samples were identified by those authors as Mikrocytos mackini in C. gigas from Kaneohe Bay, Hawaii from 1972 (code S-124A-45); as B. ostreae in experimental $O$. edulis that were transferred from Milford, Connecticut, USA, to Oxford, Maryland, USA, and 'fed tissues of moribund $O$. edulis from Pigeon Point, CA' (p. 158) from 1968 (code FMT-B-1-3); and as $B$. ostreae in $O$. edulis produced in Milford and maintained in Chincoteague Bay, Virginia, USA, from 1961 (code FK-3-1). Mercury removal from sections originally fixed in Zenker's fixative was performed as in Mitchell (1966), and chromogenic ISH was performed as above using generic and $B$. exitiosa-specific probes, BON1490 and the CaBon cocktail, respectively (Table 2).

\section{RESULTS}

\section{Bonamia-generic PCR}

Putative Bonamia spp. were detected in 9 out of 11 oyster species examined, at numerous new locations (Table 1, Fig. 2). No Bonamia spp. were detected from Isognomon sp. from Florida and Ostrea denselamellosa from Japan. Two oyster species were Bonamia-positive at some locations but not others. No Bonamia spp. were detected in Saccostrea glomerata from Whangarei Harbour, New Zealand, or in O. lurida from Drakes Estero, California, or British 


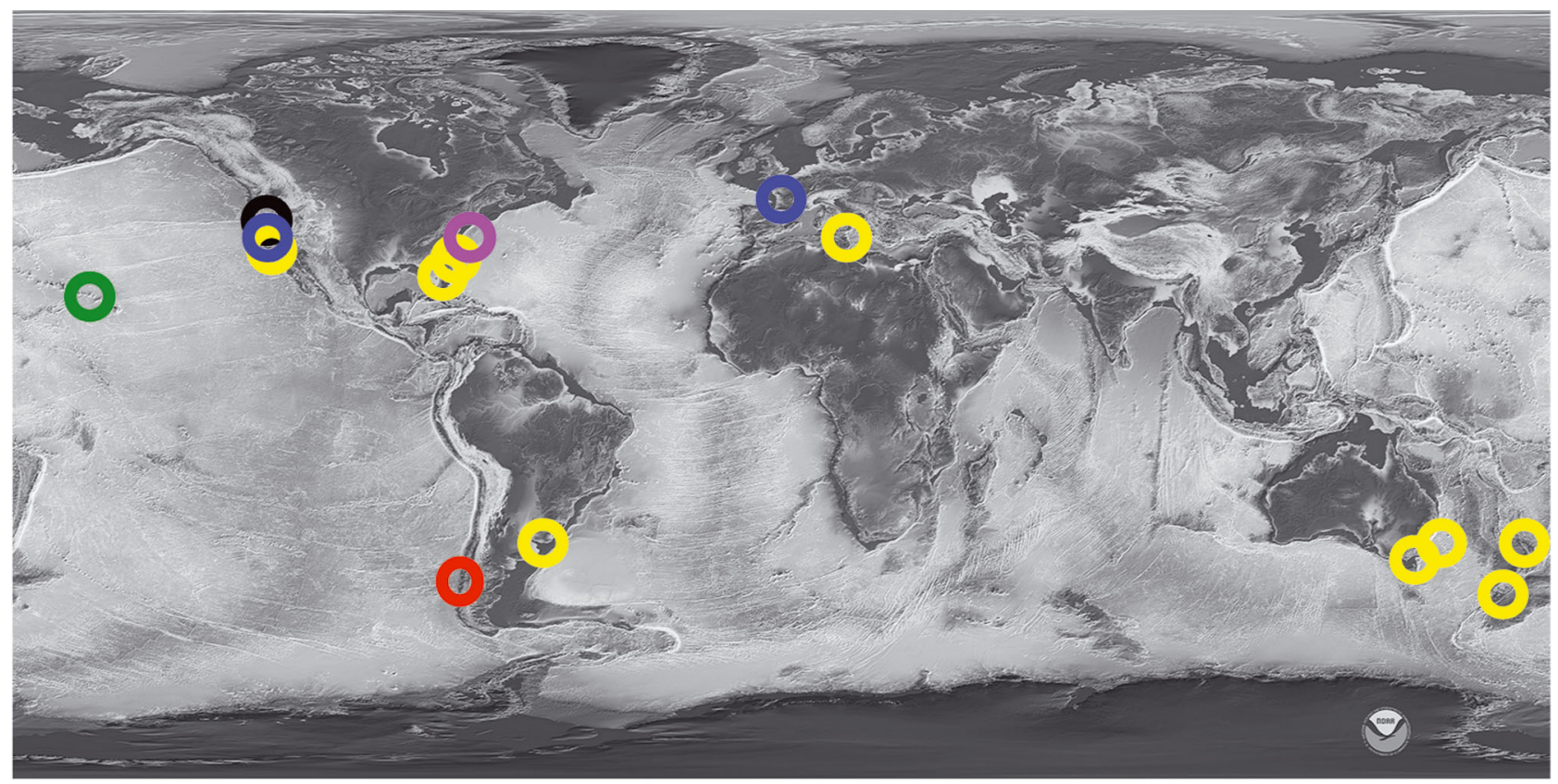

Fig. 2. Locations at which Bonamia parasites were analyzed in this study. Included are $B$. ostreae in Europe and North America (blue); B. exitiosa from North and South America, Australia, New Zealand, and the Mediterranean (yellow); B. perspora from North America (purple); and undescribed species from Hawaii (green) and California, USA (black), and Chile (red). See Table 1 for specific locations. Image: NOAA

Columbia, Canada. However, these oyster species were positive for a Bonamia sp. at other locations: $S$. glomerata in New South Wales, Australia, and in $O$. lurida from Elkhorn Slough, California. PCR prevalence of Bonamia spp. parasitism in positive samples ranged from 0.5 to $88.3 \%$ overall.

\section{SSU rDNA sequencing}

Complete SSU rDNA sequences were generated from putative Bonamia sp. parasites infecting Crassostrea ariakensis from Florida (GenBank accession number JF831807), O. stentina from Argentina (JF831801), O. edulis (JF831804 and JN040832) and O. Iurida (JF831805) from California, Dendostrea sandvicensis from Hawaii (JF831803), S. glomerata from Australia (JF831802), O. chilensis (JF495410) and O. stentina (JF831806) from New Zealand, and O. edulis from the Netherlands (JN040831).

Putative Bonamia spp. SSU rDNA consensus sequences ranged from 1749 to $1766 \mathrm{bp}$ in length, with $B$. ostreae and B. exitiosa sequences $\sim 1750 \mathrm{bp}$, $B$. perspora $1762 \mathrm{bp}$, and the Bonamia sp. from $D$. sandvicensis $1766 \mathrm{bp}$ in length. The SSU rDNA sequences of putative Bonamia sp. found in C. ariakensis from Florida, O. stentina from New Zea- land, S. glomerata from Australia, O. lurida from California, and $O$. stentina from Argentina were 99-100\% identical to the published SSU rDNA sequences of B. exitiosa from Australia (DQ312295) and New Zealand (AF337563), B. roughleyi (AF337563), Bonamia sp. in O. stentina from Tunisia (GQ385242), and Bonamia sp. in C. ariakensis from North Carolina (AY542903).

Two putative Bonamia spp. were detected in $O$. edulis from California. One sequence (JF831804) was $99 \%$ similar to B. exitiosa, while the other (JN040832) was $99 \%$ similar to published SSU rDNA sequences from B. ostreae (AF262995, AF192759). The Bonamia sp. detected in $O$. edulis from the Netherlands (JN040831) was also $99 \%$ similar to B. ostreae.

The putative Bonamia sp. SSU rDNA sequence found in $D$. sandvicensis from Hawaii was unique and only $90-91 \%$ similar to published sequences from B. exitiosa, B. ostreae, and B. perspora (DQ356000).

\section{ITS region rDNA sequencing}

Putative Bonamia sp. ITS rDNA sequences were amplified from all hosts from which presumed Bonamia sp. SSU rDNA sequences were characterized. GenBank accession numbers that were used in 
subsequent ITS rDNA phylogenetic and distance analyses are listed in Table 3. Most Bonamia sp. ITS rDNA sequences were $98-100 \%$ similar to those from $B$. exitiosa in $O$. chilensis from New Zealand. Two sets of putative Bonamia spp. ITS rDNA sequences, those from $O$. chilensis from Chile and from O. edulis from California, were only 83-85\% similar to the sequences from $B$. exitiosa; sequences from these same Bonamia spp. had been 99-100\% similar to those from $B$. exitiosa in the SSU rDNA region. There was only $83-86 \%$ ITS rDNA sequence similarity between the groups from Chile and California $O$. edulis.

Both sets of putative $B$. ostreae ITS rDNA sequences found in $O$. edulis from California and the Netherlands showed similarity to $B$. ostreae from Maine (EU709108 and EU709110): 90-99\% and 95-98\%, respectively. A BLAST search of putative Bonamia sp. ITS rDNA sequences from D. sandvicensis from Hawaii resulted in significant alignments from only Bonamia spp., Haplosporidium costale, and H. nelsoni sequences. However, these were aligning only in the SSU rDNA portion of the amplicon; there were no identical or close matches to the ITS rDNA.

\section{Molecular phylogenetics}

For the Bayesian analyses, MrModeltest v. 2.3 chose GTR + I + $\Gamma$ for the SSU and ITS rDNA data sets. For the SSU rDNA data, 10000 trees were generated $(10000000$ generations, sample frequency $=$ 1000), and the first $25 \%$ were removed as burn-in. For the ITS rDNA data, 40000000 generations were performed (sample frequency $=1000$ ), resulting in 40000 trees with the first 34999 trees removed in order to compute the consensus. A $50 \%$ majority rule Bayesian consensus tree was generated based on the remaining 5001 trees.

Parsimony and Bayesian analyse of the SSU rDNA sequences yielded trees with similar topologies (Figs. 3 \& 4). Both analyses suggested with strong support that the Bonamia sp. found in D. sandvicensis is basal to other Bonamia lineages. Both analyses portrayed $B$. perspora and $B$. ostreae as sister species, albeit with only weak support, and both placed the remaining Bonamia spp. sequences on a monophyletic clade with $B$. exitiosa and $B$. roughleyi. These included the Bonamia spp. from $O$. edulis and O. lurida from California, O. chilensis from Chile, O. puelchana and $O$. stentina from Argentina, O. stentina from Tunisia, $O$. edulis from Spain, O. stentina from New Zealand, $O$. angasi and S. glomerata from Australia, C. ariakensis from North Carolina and Florida, O. chilensis from New Zealand, and 2 partial Bonamia sp. SSU rDNA sequences from $O$. edulis from Italy.

Parsimony and Bayesian analyses of the ITS rDNA data revealed 6 well-supported clades (Figs. 5 \& 6). All of the Bonamia sp. sequences found in D. sandvicensis from Hawaii formed one monophyletic clade, the $B$. ostreae sequences from Maine, California, France, and the Netherlands formed a second, and the $B$. perspora sequences formed a third. The remaining 3 clades belonged to a single monophyletic lineage that included all the ITS region sequences associated with parasites and SSU rDNA sequences that grouped with $B$. exitiosa in the SSU rDNA-based analyses. One of these clades, shaded in orange in Figs. $5 \& 6$, comprised ITS rDNA sequences from $B$. exitiosa from $O$. chilensis as well as Bonamia spp. from $O$. stentina from New Zealand, C. ariakensis from North Carolina and Florida, O. stentina from North Carolina and South Carolina, O. stentina and O. puelchana from Argentina, O. lurida from California, O. angasi and S. glomerata from Australia, and O. stentina from Tunisia. A second clade (shaded in gray) comprised the sequences amplified from $O$. edulis from California, and a third (shaded in red) comprised the Bonamia sp. sequences amplified from O. Chilensis from Chile. Sister relationships were suggested between the Bonamia sp. from O. edulis from California and the Bonamia sp. from O. chilensis from Chile in the parsimony analysis (Fig. 5), and between the Bonamia sp. from California O. edulis and the $B$. exitiosa-containing clade in the Bayesian analysis (Fig. 6), but in neither case with strong support.

\section{Distance analyses}

Uncorrected p-distances between Bonamia spp. clades as indicated by the SSU rDNA phylogenetic analyses are shown in Table 4 . The final data set contained an analysis of 1670 positions. Uncorrected pdistances among $B$. ostreae, $B$. perspora, and the clade containing $B$. exitiosa ranged from from 0.025 to 0.031 , but were 0.084 to 0.086 in the comparisons including the Hawaiian Bonamia sp.

Mean uncorrected p-distances within each Bonamia clade as indicated by the ITS rDNA phylogenetic analyses ranged from 0.004 to 0.020 (Table 5). The greatest uncorrected p-distances (0.020) were among $B$. ostreae sequences and among the Hawaiian Bonamia sp. sequences. Values within the other clades ranged from 0.004 to 0.007 . Mean uncor- 


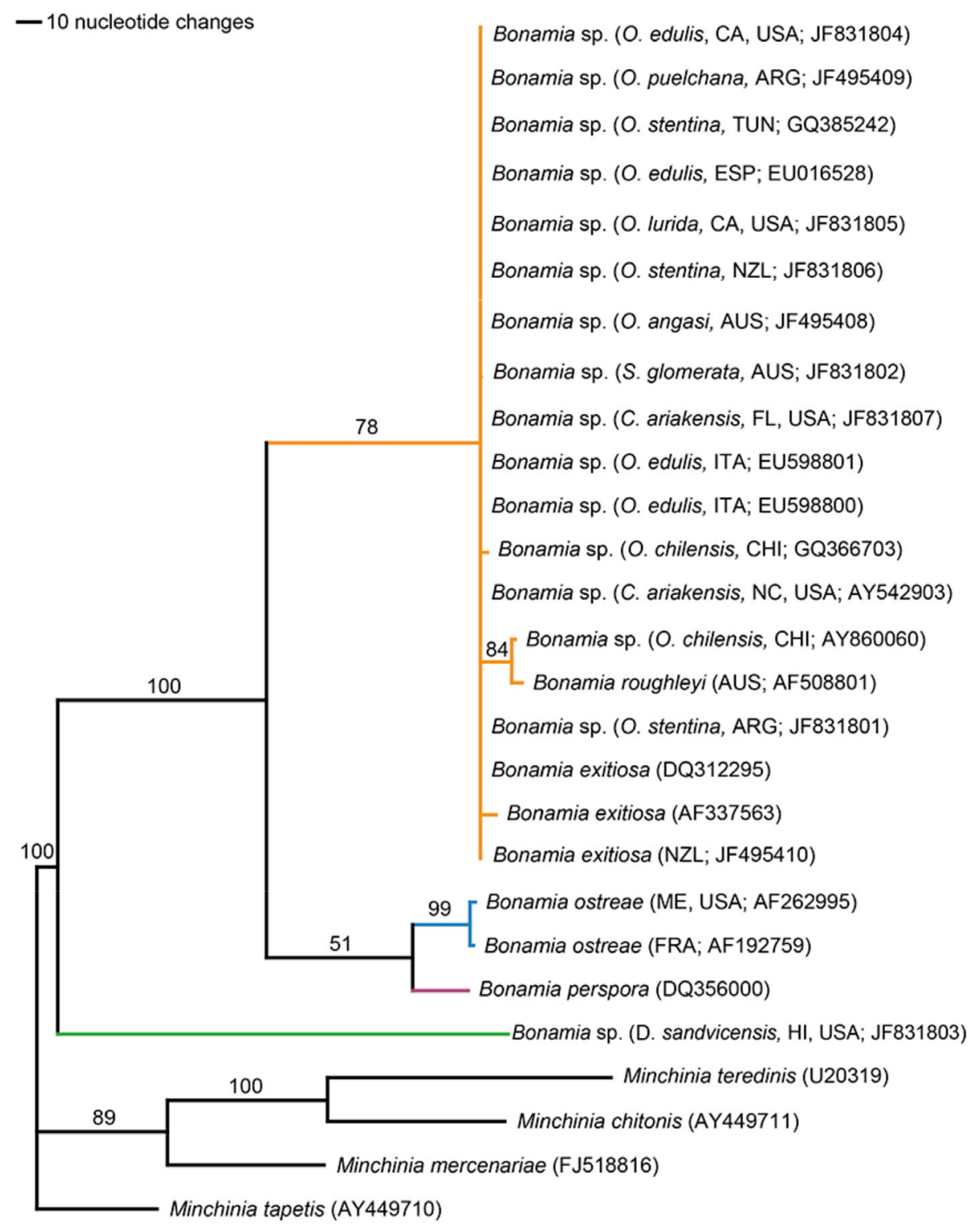

Fig. 3. Bonamia spp. small subunit (SSU) rDNA consensus phylogram. Parsimony analysis (1000 bootstrap replicates with 100 random additions) based on 285 informative characters was performed in PAUP* 4.0b10 (Swofford 2002) following alignment of Bonamia spp. SSU rDNA sequences using MAFFT v. 6 (Katoh \& Toh 2008). Gaps were treated as missing. Minchinia species were chosen as the outgroup. Colors indicate distinct Bonamia lineages. CA: California; ARG: Argentina; TUN: Tunisia; ESP: Spain; NZL: New Zealand; AUS: Australia; FL: Florida; ITA: Italy; CHI: Chile; NC: North Carolina; ME: Maine; FRA: France; HI: Hawaii. See Table 1 for full species names

rected p-distances between each Bonamia clade as indicated by the ITS rDNA analyses ranged from 0.094 to 0.324 (Table 6). The lowest p-distances corresponded to comparisons among the $B$. exitiosa clades, i.e. those related to the parasites of $O$. chilensis from Chile and $O$. edulis from California (0.094-0.169). The p-distances for all other interclade comparisons ranged from 0.259 to 0.324 . A total of 717 positions were analyzed in the ITS
rDNA final data set containing 242 sequences from $B$. exitiosa and the other Bonamia sp. parasites whose sequences were drawn to its clade; 27 sequences from the Bonamia sp. from Chilean O. chilensis; 17 sequences from the Bonamia sp. from Hawaiian $D$. sandvicensis; 19 sequences from the Bonamia sp. from California O. edulis; 17 sequences from $B$. perspora; and 31 sequences from B. ostreae. 


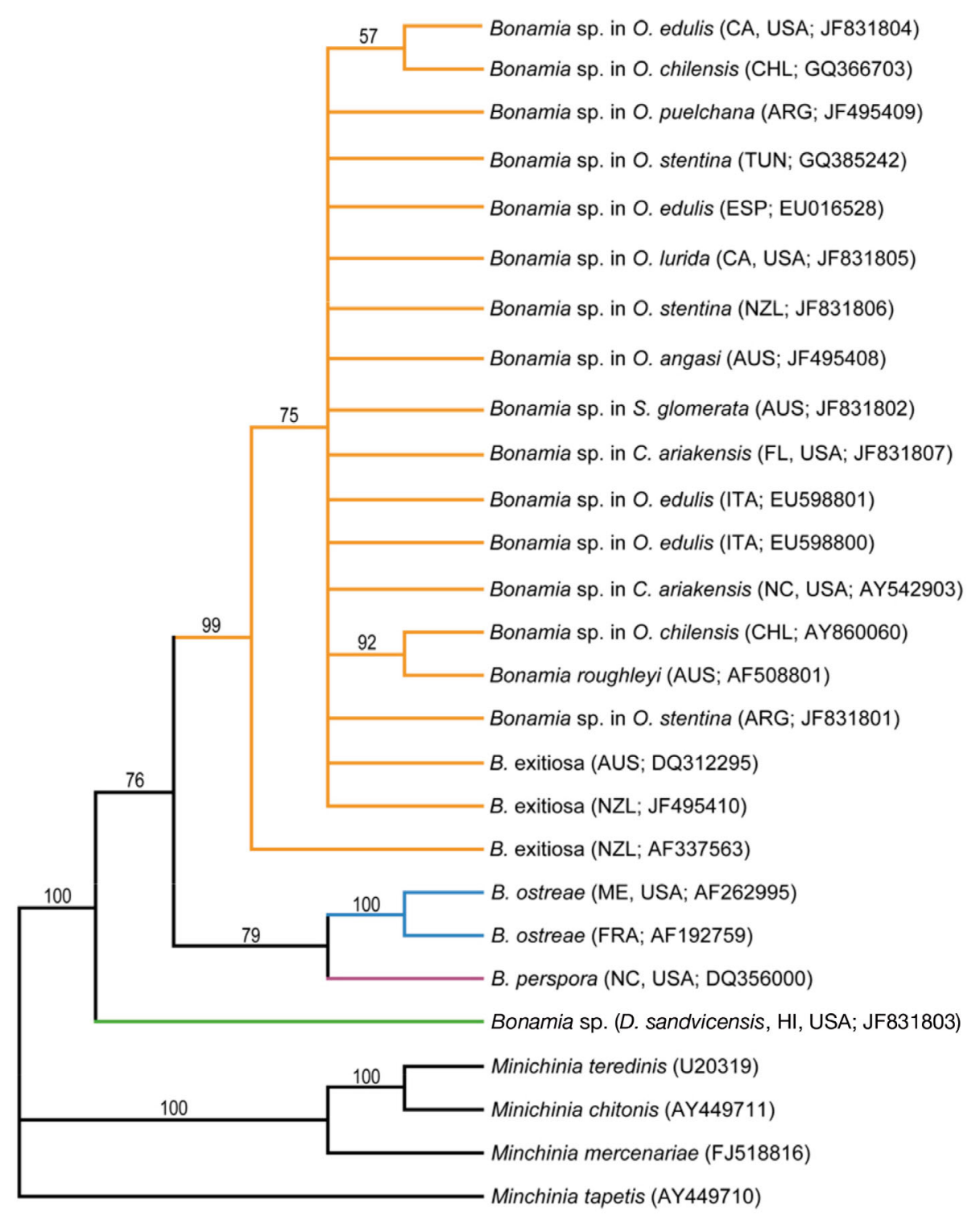

Fig. 4. Bonamia spp. small subunit (SSU) rDNA Bayesian $50 \%$ majority rule consensus tree. Bayesian inference analysis was conducted in MrBayes v. 3.1.2 (Ronquist \& Huelsenbeck 2003) using model GTR $+\mathrm{I}+\Gamma$, as determined by MrModeltest v. 2.3, following alignment using MAFFT v. 6 (Katoh \& Toh 2008) of Bonamia spp. SSU rDNA sequences. Ten thousand trees were produced $(10000000$ generations, sample frequency $=1000)$, with $25 \%$ removed as burn-in. The consensus tree was generated using PAUP *4.0b10 (Swofford 2002) using Minchinia species as the outgroup. Colors indicate distinct Bonamia lineages. See Fig. 3 legend for location abbreviations; see Table 1 for full species names

Table 4. Mean uncorrected p-distance between group means for the small subunit rDNA data set. (below diagonal), and standard error estimates obtained by 1000 bootstrap replicates (above diagonal)

\begin{tabular}{|lcccc|}
\hline Species group & B. exitiosa & $\begin{array}{c}\text { Hawaiian } \\
\text { Bonamia sp. }\end{array}$ & B. ostreae & B. perspora \\
\hline Bonamia exitiosa & - & 0.007 & 0.004 & 0.004 \\
Hawaiian Bonamia sp. & 0.086 & - & 0.007 & 0.007 \\
Bonamia ostreae & 0.031 & 0.086 & - & 0.004 \\
Bonamia perspora & 0.025 & 0.084 & 0.029 & - \\
\hline
\end{tabular}

\section{Oyster mt16S rDNA sequencing}

Mitochondrial 16S rDNA sequencing of infected host species confirmed the morphological identifications of oysters. GenBank BLAST searches revealed that the $O$. edulis mt16S rDNA sequence from California was identical to deposited $O$. edulis $16 \mathrm{~S}$ rDNA sequences (DQ093488， DQ280032). 


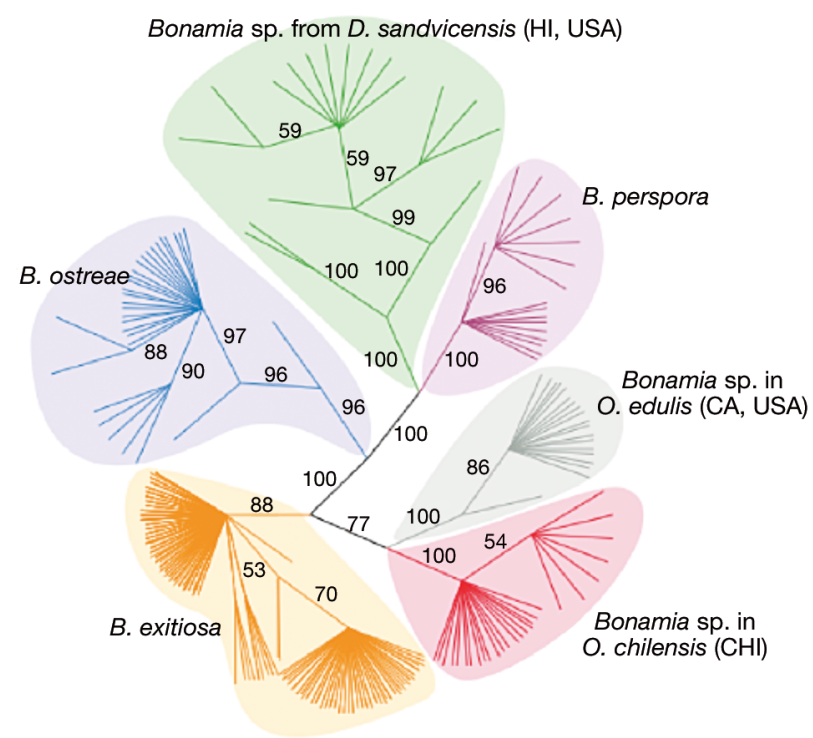

Fig. 5. Bonamia spp. internal transcribed spacer (ITS) rDNA unrooted parsimony consensus tree (50\% majority rule). Parsimony analysis (100 bootstrap replicates with 10 random additions) conducted using a new technology search in TNT v. 1.1 (Goloboff et al. 2008) following alignment in MAFFT v. 6 (Katoh \& Toh 2008) of Bonamia spp. ITS rDNA sequences. Bootstrap values less than 50 are not shown. The consensus tree was generated using PAUP* 4.0b10 (Swofford 2002). Colors indicate distinct Bonamia lineages. See Fig. 3 legend for location abbreviations; see Table 1 for full species names

Table 5. Mean uncorrected p-distance within Bonamia clades for the internal transcribed spacer region rDNA data set. See Table 1 for full species names

\begin{tabular}{|lcc|}
\hline Bonamia clade & p-distance & $\begin{array}{c}\text { No. sequences } \\
\text { analyzed }\end{array}$ \\
\hline $\begin{array}{l}\text { Bonamia exitiosa } \\
\text { Chilean Bonamia sp. }\end{array}$ & 0.005 & 242 \\
$\begin{array}{l}\text { in O. chilensis } \\
\text { Hawaii Bonamia sp. }\end{array}$ & 0.007 & 27 \\
$\begin{array}{l}\text { in D. sandvicensis } \\
\text { California Bonamia sp. } \\
\text { from O. edulis }\end{array}$ & 0.004 & 17 \\
$\begin{array}{l}\text { Bonamia perspora } \\
\text { Bonamia ostreae }\end{array}$ & 0.005 & 19 \\
\hline
\end{tabular}

The mt16S rDNA sequence of $O$. stentina was $99 \%$ similar to O. equestris ( $=O$. stentina; Shilts et al. 2007; AY376603) and $O$. aupouria $(=O$. stentina; Shilts et al. 2007; AF052064). The O. lurida mt16S rDNA sequence from California was identical to that of O. lurida from British Columbia, Canada (FJ768589). The $O$. sandvicensis mt16S region rDNA was $99 \%$ similar to that of the fingerprint oyster, Dendostrea crenulifera (EU815984, EU815985), and 94-95\% similar to Alectryonella plicatula Gmelin 1790 (AF052072).

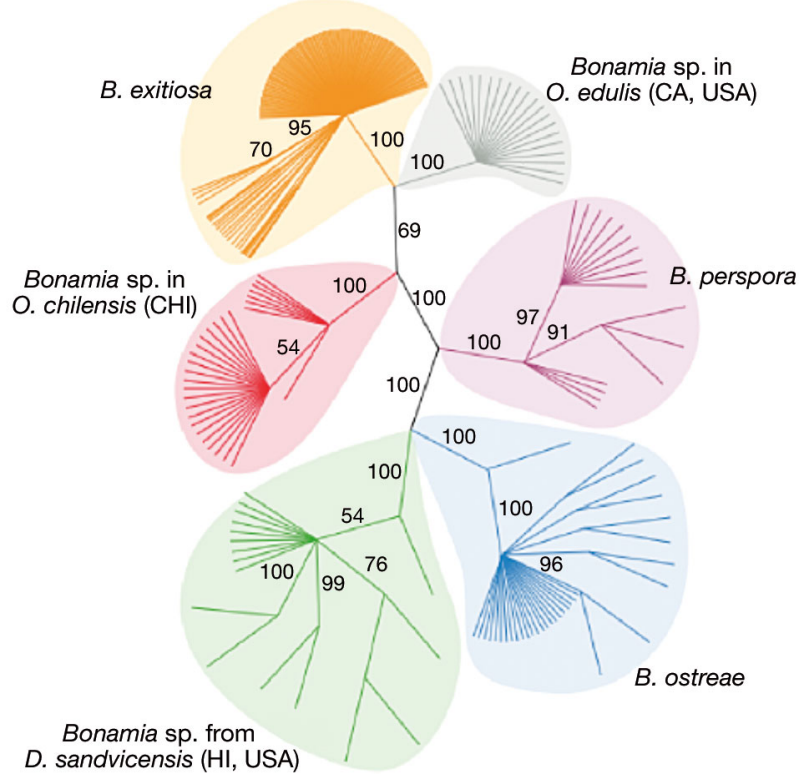

Fig. 6. Bonamia spp. internal transcribed spacer (ITS) rDNA unrooted Bayesian consensus tree (50\% majority rule). Bayesian inference analysis was conducted in MrBayes v. 3.1.2 (Ronquist \& Huelsenbeck 2003) using model GTR + I + $\Gamma$, as determined by MrModeltest v. 2.3, following alignment using MAFFT v. 6 (Katoh \& Toh 2008) of Bonamia spp. ITS rDNA sequences. A total of 40000 trees were produced $(40000000$ generations, sample freq. $=1000)$, with the first 34999 trees removed in order to compute a consensus tree. Posterior probabilities less than 50 are not shown. A consensus of the remaining 5001 trees was generated using PAUP* 4.0b10 (Swofford 2002). Colors indicate distinct Bonamia lineages. See Fig. 3 legend for location abbreviations; see Table 1 for full species names

There were no D. sandvicensis sequences in GenBank. Molecular confirmation of the identity of Bonamia spp. PCR-positive O. stentina from Argentina was performed by Dr. Ami Wilbur at the University of North Carolina Wilmington (pers. comm.), and confirmation of the identity of $O$. stentina from Tunisia was described in Hill et al. (2010).

\section{Histopathology and in situ hybridization}

Microcells were observed in at least one individual from each oyster host that was PCR-positive for Bonamia spp. except $O$. stentina from New Zealand. New observations in O. lurida from California, $O$. edulis from California, and D. sandvicensis from Hawaii are illustrated in Fig. 7. The histological presentation of the parasite in each host was typical of infection by 'microcell haplosporidian' (Carnegie \& Cochennec Laureau 2004) Bonamia spp.: parasite 
Table 6. Mean uncorrected p-distances among Bonamia clades for the internal transcribed spacer region rDNA data set. (below diagonal), and standard error estimates obtained by 1000 bootstrap replicates (above diagonal)

\begin{tabular}{|lcccccc|}
\hline Species group & $\begin{array}{c}\text { Bonamia } \\
\text { exitiosa }\end{array}$ & $\begin{array}{c}\text { Bonamia sp. } \\
\text { (HI, USA) }\end{array}$ & $\begin{array}{c}\text { Bonamia sp. } \\
\text { (Chile) }\end{array}$ & $\begin{array}{c}\text { Bonamia sp. } \\
\text { (CA, USA) }\end{array}$ & $\begin{array}{c}\text { Bonamia } \\
\text { perspora }\end{array}$ & $\begin{array}{c}\text { Bonamia } \\
\text { ostreae }\end{array}$ \\
\hline Bonamia exitiosa & - & 0.022 & 0.012 & 0.013 & 0.021 & 0.021 \\
Bonamia sp. (HI, USA) & 0.298 & - & 0.022 & 0.023 & 0.020 & 0.021 \\
Bonamia sp. (Chile) & 0.094 & 0.284 & - & 0.016 & 0.022 & 0.021 \\
Bonamia sp. (CA, USA) & 0.104 & 0.324 & 0.169 & - & 0.022 & - \\
Bonamia perspora & 0.275 & 0.259 & 0.295 & 0.292 & 0.021 \\
Bonamia ostreae & 0.263 & 0.313 & 0.292 & 0.286 & - \\
\hline
\end{tabular}

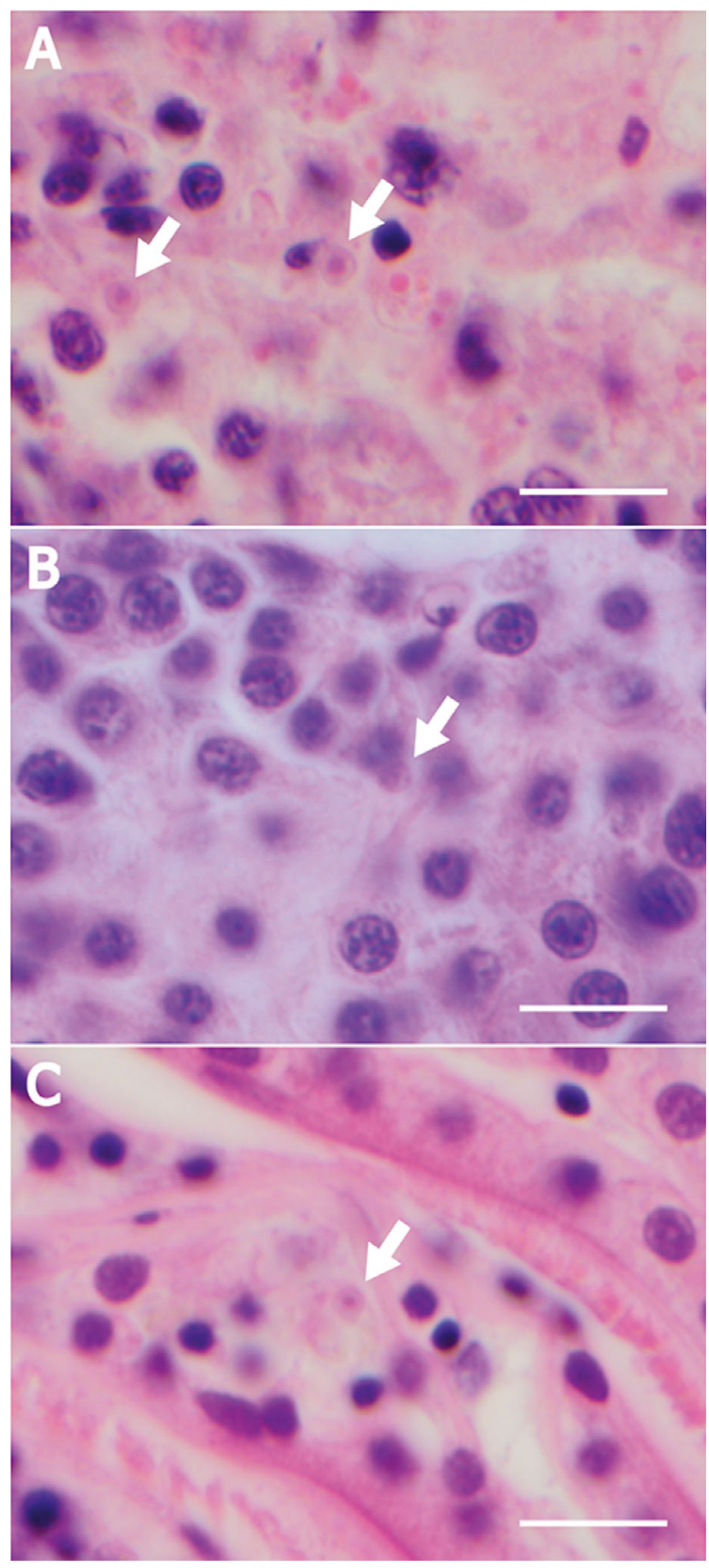

cells were generally intrahemocytic, sometimes extracellular where hemocytes had lysed, with no presentation of more conventionally haplosporidian forms such as spores or large multinucleate plasmodia. Infections were light to moderate in intensity except in C. ariakensis, which can be heavily infected (Burreson et al. 2004), and light to moderate hemocytosis was typically observed as a host response. Disruption of tissue was only modest.

In situ hybridization using digoxigenin-labeled probes was performed on 4 C. ariakensis from Florida, 4 O. lurida from California (3 individuals from the 2004 sample and 1 individual from the 2009 sample), 4 O. edulis from California, and 3 O. stentina from New Zealand. Hybridization within the tissues of the $B$. exitiosa-specific probes, which target SSU rRNA, was observed in C. ariakensis and in O. lurida and $O$. edulis (Fig. 8A,B), but not conclusively in the New Zealand O. stentina. Most infections as detected using this method were light. No case showed hybridization to the $B$. ostreae-specific probe, and positive and negative controls performed appropriately (Fig. 8C,D).

ISH using digoxigenin-labeled probes was also performed on 3 archival samples to verify microcell observations by histopathology and ultrastructural methods described in Farley et al. (1988). Parasites originally identified as Mikrocytos mackini in Crassostrea gigas from Kaneohe Bay, Hawaii, from 1972 hybridized to both the generic Bonamia spp. probe and the $B$. exitiosa-specific probes, as did the ' $B$. ostreae' infecting $O$. edulis in oysters maintained in Chincoteague Bay (an indication that the generic identification of the latter parasite was correct, but

Fig. 7. Light microscopy of Bonamia spp. in hematoxylin \& eosin-stained oyster tissue sections. (A) Bonamia exitiosa microcells (arrows) in an Ostrea lurida section from California, USA. (B) Bonamia exitiosa-like sp. microcell (arrow) in an O. edulis section from California. (C) Bonamia sp. microcell (arrow) in the gills of a Dendostrea sandvicensis section from Hawaii, USA. Scale bars $=10 \mu \mathrm{m}$ 


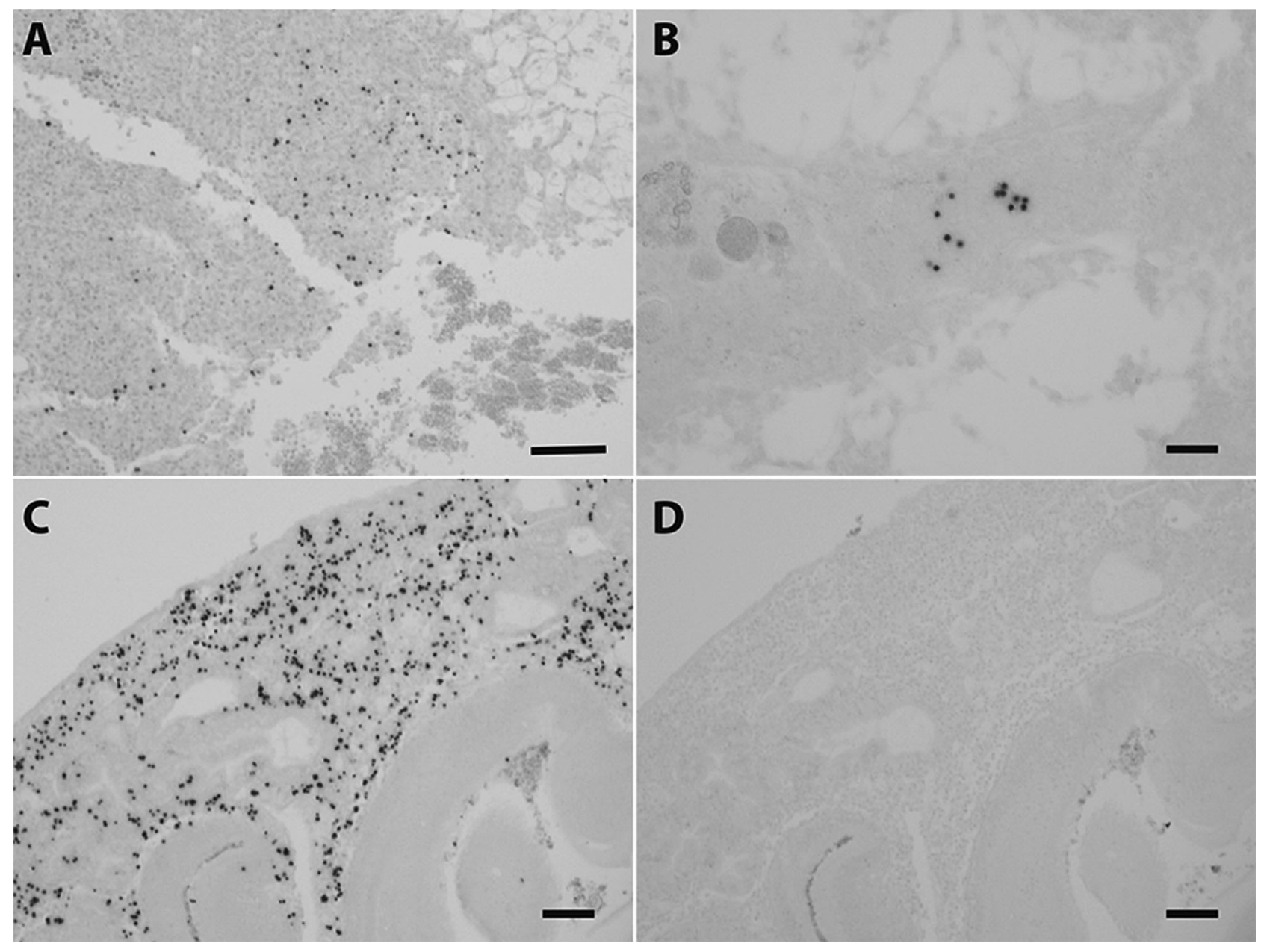

Fig. 8. In situ hybridization (ISH) images for molecular confirmation of histopathological diagnoses. Digoxigenin-labeled probe-based assays were specific for members of the Bonamia exitiosa small subunit rDNA clade in all cases. (A) Hybridization to B. exitiosa in Ostrea lurida from California, USA. Scale bar $=50 \mu \mathrm{m}$. (B) Hybridization to Bonamia sp. in O. edulis from California, USA. Scale bar $=20 \mu \mathrm{m}$. (C) Positive control hybridization to B. exitiosa infecting Crassostrea virginica from North Carolina, USA. Scale bar $=50 \mu \mathrm{m}$. (D) No-probe control. Scale bar $=50 \mu \mathrm{m}$

the specific identification was not). No hybridization to any Bonamia spp. probes occurred to parasites in the sample of experimental $O$. edulis that were 'fed tissues of moribund $O$. edulis from Pigeon Point, $\mathrm{CA}^{\prime}$ (p. 158, Farley et al. 1988) from 1968, which were originally identified as B. ostreae. Again, all controls performed as expected.

FISH was performed on $D$. sandvicensis from Hawaii using probes HIBon-167 and HIBon-634 (Table 2) specific to this particular Bonamia species. Hybridization was observed in an oyster (the only oyster evaluated) that was diagnosed as a moderate, systemic infection by histology (Fig. 9A). The no-probe control showed no hybridization, and hybridization with these probes did not occur in samples infected with other known Bonamia species (e.g. B. exitiosa,
Fig. 9B). Fluorescently labeled B. exitiosa-specific probes did not hybridize to the $D$. sandvicensis section (Fig. 9C), though they did to B. exitiosa-infected C. virginica (Fig. 9D).

\section{DISCUSSION}

From this study, it is apparent that Bonamia species have a wider geographic and host distribution and are more diverse than first appreciated. Bonamia spp. were detected by PCR, histology, and ISH in most oyster hosts and locations examined (Table 1). Bonamia exitiosa appears to be particularly widespread, infecting a variety of oyster hosts around the world, while $B$. ostreae and $B$. perspora seem to be 


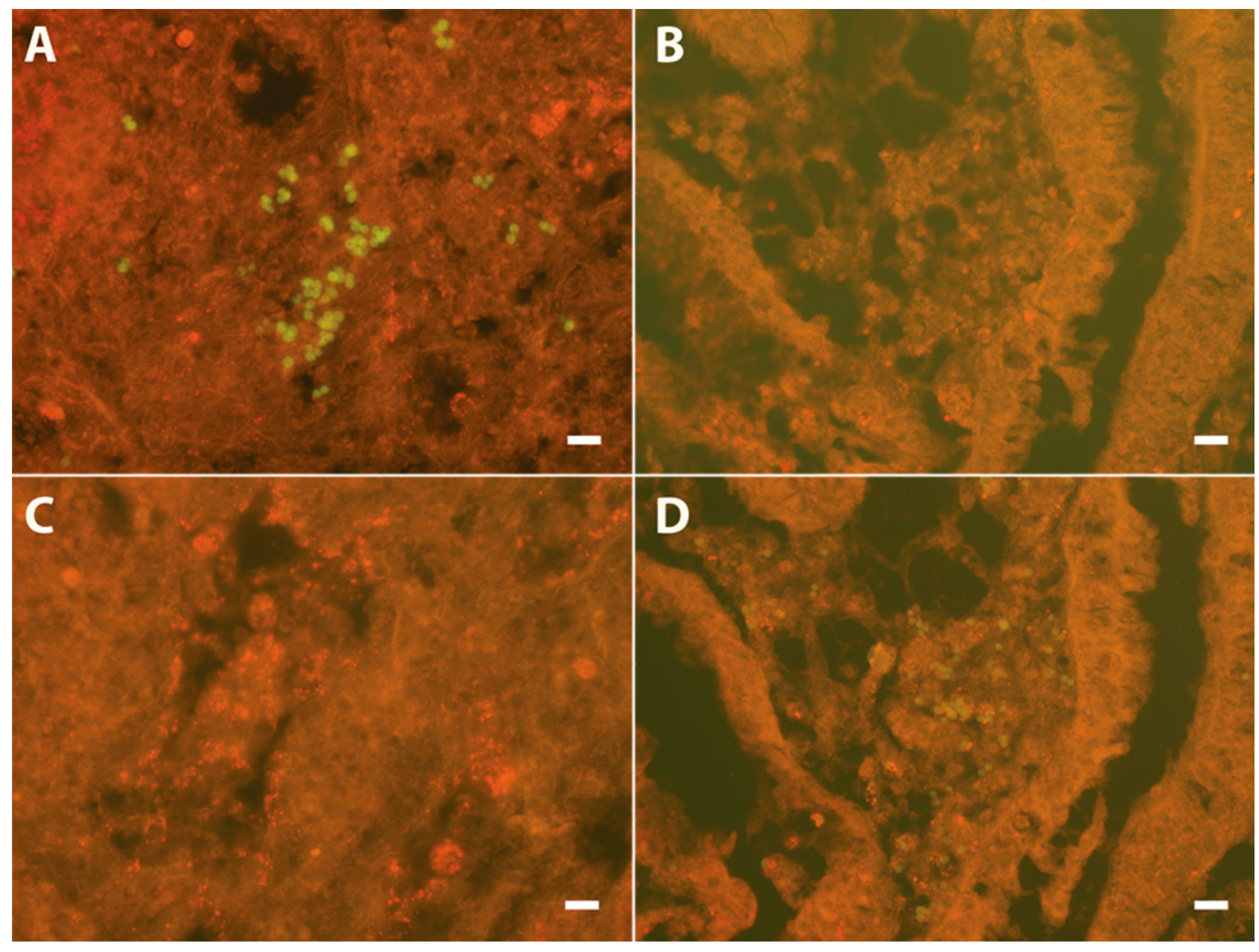

Fig. 9. Fluorescent in situ hybridization to the Bonamia sp. in Dendostrea sandvicensis from Hawaii, USA. (A) Hawaiian Bonamia sp.-specific probes hybridized to a Bonamia sp.-infected D. sandvicensis section. (B) Hawaiian Bonamia sp.-specific probes hybridized to a $B$. exitiosa-infected Crassostrea virginica section. (C) B. exitiosa-specific probes hybridized to a Bonamia sp.-infected D. sandvicensis section. (D) Bonamia exitiosa-specific probes hybridized to a section of $B$. exitiosa-infected Crassostrea virginica from North Carolina, USA. Scale bars $=20 \mu \mathrm{m}$

host specialists maintaining well-defined geographic ranges. Cryptic diversity was uncovered in Hawaiian Dendostrea sandvicensis, Chilean Ostrea chilensis, and Californian $O$. edulis hosts.

\section{Bonamia exitiosa and its relatives}

Phylogenetic analyses of SSU and ITS rDNA revealed the affinity of most newly characterized $B o$ namia sp. sequences from various hosts to $B$. exitiosa. In all phylogenetic analyses (Figs. 3-6), Bonamia sequences found in Crassostrea ariakensis from Florida and North Carolina, O. stentina from North Carolina, South Carolina, Argentina, Tunisia, and New Zealand, $O$. puelchana from Argentina, O. lurida from California, O. angasi and Saccostrea glomerata from Aus- tralia, and O. chilensis from New Zealand appeared in the same clade as B. exitiosa. Bonamia spp. sequences from $O$. edulis from California and $O$. chilensis from Chile appeared in the $B$. exitiosa clade in SSU rDNA phylogenetic analyses (Figs. $3 \& 4$ ), but diverged from this clade in the ITS rDNA analyses (Figs. $5 \& 6$ ). Histological presentation of parasites in these clades was similar in all cases, underscoring the limited utility of microscopy for uncovering Bonamia diversity. The more high-resolution ITS rDNA-based analyses were capable of resolving distinct lineages, and thus are useful for conservatively determining the species boundaries of $B$. exitiosa. We conclude that all the Bonamia sp. sequences appearing in the same clade as $B$. exitiosa in both the SSU and ITS rDNA phylogenetic analyses should be identified as $B$. exitiosa. Inclusion within $B$. exitiosa of the para- 
sites from O. chilensis in Chile and O. edulis in California may not be justified, and these lineages may represent novel species. Further analyses using more expansive genetic analyses and experimental challenge systems may provide more perspective here. There was some more modest ITS rDNA sequence divergence evident within the $B$. exitiosa clade (Figs. 5 \& 6), but this had no strongly supported pattern with regard to geography or host that could be discerned from these analyses.

ISH detection not only of a member of the genus Bonamia but of a parasite closely related to $B$. exitiosa in archival histological materials of $C$. gigas from Hawaii and $O$. edulis from Chincoteague Bay, Virginia, was unexpected. Without ITS rDNA region sequence data, it is impossible to know whether these parasites belonged to the $B$. exitiosa lineage proper, to the 2 related lineages comprising sequences from the Bonamia sp. infecting O. chilensis in Chile and $O$. edulis in California, or to another related group; ISH using the CaBon probe cocktail of Hill et al. (2010) could not distinguish among these possibilities. Given the very wide geographic and host range of $B$. exitiosa, it is conceivable that our observations revealed the presence of this particular parasite. Determining whether these locations presently harbor $B$. exitiosa or a related species in one host or another (C. gigas or D. sandvicensis in Hawaii, C. virginica in Virginia) should be a priority for aquatic animal health managers.

Histopathology and ISH provided visual confirmation of infections for all B. exitiosa and Bonamia spp. observations (Figs. 7-9), except for the parasite amplified from $O$. stentina from New Zealand. For the New Zealand samples, there was considerable tissue loss during the slide washing process, so it is possible that Bonamia cells were lost along with the tissue. However, B. exitiosa has been visualized in O. stentina from North Carolina, South Carolina, Argentina, and Tunisia, so this oyster is a known host. It is plausible, therefore, that $B$. exitiosa also infects not only $O$. chilensis but $O$. stentina as well in New Zealand.

\section{Bonamia ostreae and $B$. perspora}

Based on the locations surveyed and previous studies, $B$. ostreae and $B$. perspora demonstrate narrower host and geographic ranges than $B$. exitiosa. Bonamia ostreae has only been detected in $O$. edulis. Putative Bonamia sp. SSU and ITS rDNA sequences found in $O$. edulis from the Netherlands and some sequences found in $O$. edulis from California are within the same clade as $B$. ostreae from Maine and France (Figs. 3-6). This study did not examine southern hemispheric $O$. edulis, which have been reported to occur in Australia (Morton et al. 2003) and in South Africa (FAO 2007-2011, Haupt et al. 2010). Therefore, the question remains as to whether $B$. ostreae is present within its type host in the Southern Hemisphere. A host specialist strategy and a potential inability to survive variable environmental conditions (i.e. it prefers cool, temperate climates) may provide barriers to dispersal for this particular species.

The data collected to date suggest that $B$. perspora, like $B$. ostreae, is also a host specialist, but with an even more restricted geographic distribution. B. perspora has only been detected in $O$. stentina from North Carolina (Carnegie et al. 2006), and B. perspora was never detected in $O$. stentina evaluated elsewhere (Argentina, Tunisia, and New Zealand). One explanation could be that $B$. perspora has only been found at very low prevalence $(<5.6 \%$ prevalence; Carnegie et al. 2006), so perhaps larger sample sizes will be needed in order to detect this parasite. Alternatively, B. perspora could have been established in North Carolina O. stentina after a geographic separation of conspecific hosts. More sampling would need to be done in order to test either hypothesis.

While a sister relationship between $B$. perspora and $B$. ostreae was suggested by both the parsimony and Bayesian analyses of SSU rDNA data (Figs. 3 \& 4), it was not well supported. Analyses of additional loci may shed further light on this relationship. The fact that the ITS rDNA-based analyses failed to show this sister relationship should not be taken as lack of support. The divergence of ITS rDNA sequences among Bonamia species may result in alignments that are reliable intra-specifically but unreliable across species, making resolution of inter-specific relationships impossible using this locus.

\section{Bonamia sp. in Dendostrea sandvicensis from Hawaii}

While analyses based on SSU rDNA sequences do not provide sufficient resolution to distinguish all Bonamia species, the divergence of this parasite's sequence at this locus as well as the phylogenetic analyses based on this region suggest that the species found in D. sandvicensis from Hawaii is a novel species.

We expected that the putative Bonamia sp. SSU rDNA sequence detected in $D$. sandvicensis would be 
another observation of $B$. exitiosa, since this parasite was detected by ISH in archival $C$. gigas tissue sections taken in 1972 from Hawaii. However, when contemporary sequences were compared with those from other described Bonamia spp., they were only 90-91\% similar, whereas the identity among currently described Bonamia species is 94-98\%. The Hawaiian Bonamia sp. was $85 \%$ similar to SSU rDNA of Minchinia tapetis (AY449710) and M. mercenariae (FJ518816), species within the sister genus to Bonamia in the haplosporidian phylogeny (Reece et al. 2004). The variability in SSU rDNA among Bonamia species is low (similarity $\geq 91 \%$ among Bonamia spp. overall, and $\geq 97 \%$ when the Hawaiian Bonamia sp. is excluded) when compared with other closely related taxa, such as Minchinia species, where similarity ranges from 86 to $91 \%$ between SSU rDNA sequences of differing species within the genus (from BLAST results). Based on SSU rDNA sequencing data alone, then, it is unlikely that the Bonamia sp. from Hawaii is $B$. exitiosa or any other described species. The presentation of the parasite conforms to that of typical microcell haplosporidian Bonamia species: a 2-3 $\mu \mathrm{m}$, uninucleate cell predominantly associated with hemocytes (Fig. 7C). It is unlike the presentation of Minchinia spp. and the atypical B. perspora, in which uninucleate cells would be primarily extracellular and accompanied by multinuclear and sporogonic forms (Carnegie et al. 2006, Ford et al. 2009). Therefore, while this Bonamia sp. is relatively divergent from the other Bonamia species, its histological presentation does support its inclusion in the genus Bonamia.

Both SSU rDNA sequence phylogenetic analyses provided strong support for the inclusion of the Hawaiian Bonamia sp. in the Bonamia clade (Figs. 3 $\& 4)$. The ITS rDNA analyses provided further support for this being a distinct species as the Bonamia sp. sequences obtained from $D$. sandvicensis form a distinct monophyletic clade in unrooted trees (Figs. 5 \& 6). The basal position of the parasite in the SSU rDNA-based analyses in particular raises interesting questions. First, did the Bonamia genus arise in cool temperate euhaline environments, in which its members have generally been known to exist? Or, given the basal position of a tropical Bonamia sp. infecting a tropical oyster host, is this a genus whose origins are among the fauna of tropical seas? Related to this is the phylogenetic position of the host itself. Bonamia spp. typically infect members of the families Ostreinae (which includes the genus Ostrea) and Crassostreinae (which includes Crassostrea and Saccostrea; Harry 1985), but D. sandvicensis, which the basal Hawaiian Bonamia sp. infects, is a member not of the Ostreinae but of the family Lophinae, which includes generally tropical genera (Harry 1985). Members of the Lophinae are thought to be evolutionarily older than the Ostreinae, based on paleontological analyses (Stenzel 1971) and molecular evidence including partial 28S rDNA (Littlewood 1994) and 16S mtDNA sequences (Jozefowicz \& Ó Foighil 1998). Therefore, if the placement of the Hawaiian Bonamia sp. at the base of the entire Bonamia clade is correct, origins of the genus Bonamia not only in the tropics but also among tropical lophine oyster hosts might be hypothesized.

A second and more important question arises from the basal position of the Hawaiian Bonamia sp. What does the phylogeny say about the evolution of Bonamia sp. life strategies? Of all the known Bonamia spp., the only one that clearly has retained the ancestral haplosporidian traits of extracellular infection by various vegetative and sporogonic cell forms and, presumably, a complex life cycle is $B$. perspora. The other Bonamia spp., including the Hawaiian Bonamia sp. and the $B$. exitiosa-related lineages infecting $O$. chilensis in Chile and O. edulis in California, are typical microcell haplosporidians (Carnegie \& CochennecLaureau 2004), presenting small uninucleate ameboid cells almost exclusively, intracellularly infecting oyster hemocytes, and displaying (presumably) direct transmission among hosts. Yet while its histological presentation and expression of cell forms suggests that $B$. perspora should be basal to the other Bonamia spp., which would lead to the parsimonious hypothesis of a single adoption of the microcell haplosporidian life cycle (intracellularity, abandonment of sporulation, direct transmission; see Fig. 10A) in the Haplosporidia, the SSU rDNA-based phylogenies suggest that it is not. Three possible explanations are thus raised. First, the SSU rDNA-based gene trees may be inaccurate representations of the species relationships. Second, switching between life strategies actually happened several times in the evolution of the genus. The microcell haplosporidian life strategy may have been adopted on 3 separate occasions, in lineages giving rise to $B$. ostreae, to the Hawaiian Bonamia sp., and to the B. exitiosa/Chilean Bonamia sp./Californian Bonamia sp. lineage (Fig. 10B). Or, less plausibly, it may have been adopted once, but with the 'conventional' haplosporidian strategy arising once again on the lineage giving rise to $B$. perspora (Fig. 10C). A third possible explanation is that all Bonamia spp. can pursue either strategy, depending on host and environmental circumstances, and that our present perspective is impaired by our limited observations. Comparative genomic analyses 

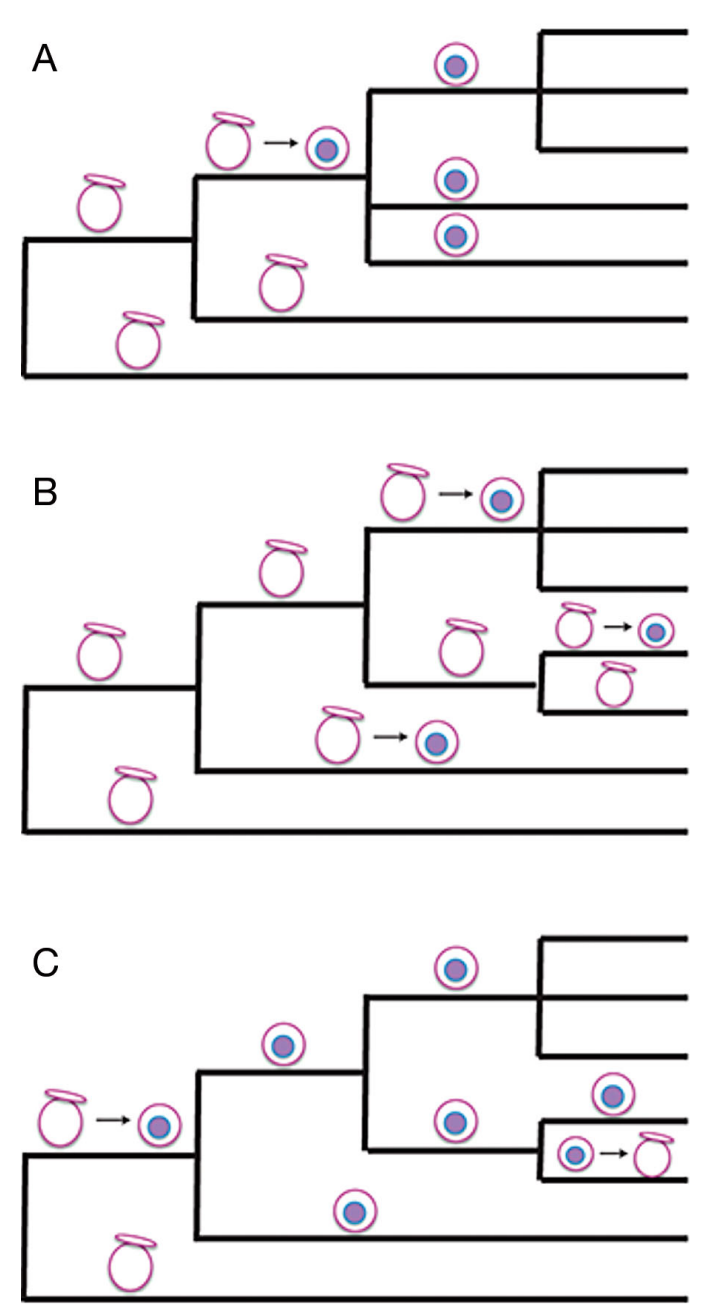

Bonamia exitiosa

Bonamia sp. (Ostrea chilensis, Chile)

Bonamia sp. (Ostrea edulis, California)

Bonamia ostreae

Bonamia perspora

Bonamia sp. (Dendostrea sandvicensis, Hawaii)

Minchinia spp.

Conventional haplosporidian life strategy

Microcell haplosporidian life strategy

Fig. 10. Models of life history evolution in the genus Bonamia. (A) Most parsimonious tree based on morphology, with a single adoption of the microcell haplosporidian strategy of direct transmission of uninucleate, generally intrahemocytic microcells. (B) First alternative model overlaid on the small subunit (SSU) rDNA phylogenies determined herein, implausibly hypothesizing 3 separate adoptions of the microcell haplosporidian strategy. (C) Second alternative overlaid on the SSU rDNA phylogenies, hypothesizing a single adoption of the microcell haplosporidian strategy and then a subsequent restoration of a convention haplosporidian strategy. A fourth model (not illustrated) would hypothesize that Bonamia species can alternate between the 2 strategies, depending on host and environmental conditions

may ultimately reveal whether the architecture underlying sporulation and the conventional haplosporidian life strategy has been lost or is still maintained in species such as B. ostreae and B. exitiosa.

\section{Samples with no detection of Bonamia species}

Non-detection by PCR of a Bonamia sp. in some samples may have been due to low sample sizes in some cases (Table 1), if not an actual absence from some locations. There has never been a report of a Bonamia sp. infecting $O$. denselamellosa in Japan, although this species has not received much parasitological attention. While Isognomon sp. from Florida were also negative, it is not known whether members of the bivalve family Pteriidae are susceptible to Bonamia sp. parasitism at all. We must also consider the possibility that a Bonamia sp. might have been present in some samples but genetically 
divergent at primer binding sites, leading to false negative results.

The most noteworthy non-observation was of $B$. roughleyi in Australian or New Zealand samples of $S$. glomerata. Sequences bearing the B. roughleyi-diagnostic signatures identified by Cochennec-Laureau et al. (2003) were not found in any sample at any location, and cryptic ITS rDNA region lineages such as were observed in Chilean O. chilensis and Californian $O$. edulis, which might indicate the presence of B. roughleyi, were not observed in Bonamia-positive oysters from the region. Our present work supports the conclusions of Hill et al. (2010) and Carnegie et al. (2014) that there is no genetic basis for identifying any Bonamia sp. besides B. exitiosa in Australia or New Zealand.

\section{Inter- and intra-clade distances, and patterns of diversity}

Two observations emerge from the phylogenetic analyses that are reinforced by the distance analyses. First, the Bonamia sp. from Hawaii is the most divergent Bonamia species known based on SSU rDNA sequence data, with p-distances in every comparison more than twice as great as those of any of the other Bonamia species (Table 4). While the ITS rDNA-based p-distances do not show the same level of inter-lineage divergence (Table 6), this may again relate to the unreliability of the ITS rDNA-based analyses for reconstructing interspecific relationships. The ITS rDNA data are stronger with regard to intra-specific comparisons, and here another notable observation emerges: while the ITS rDNA-based analyses showed divergence to be greatest among the sequences from the Hawaiian Bonamia sp. ( $p=0.20$, Table 5), the intra-specific divergence among $B$. ostreae sequences was just as high. Intra-specific divergence among sequences of $B$. perspora, $B$. exitiosa, and the $B$. exitiosa-related lineages was lower by a factor of $3-5$, and divergence was unrelated to the intensity of sampling of the lineages. While one may speculate that the lack of divergence in $B$. exitiosa may represent a recent radiation, particularly given the very recent detection of this parasite (and its relatives) over such a broad range, we must recognize that the new observations of $B$. exitiosa are due partly to a new interest in applying molecular tools to uncover Bonamia diversity. It does not necessarily indicate a rapid radiation and dispersal, i.e. a $B$. exitiosa panzootic. The similar lack of divergence in $B$. perspora, a very different parasite in its display of the ancestral haplosporidian cell forms and presumably life cycle, would also have to be explained. Further exploration of the patterns of diversity within and among Bonamia lineages must await application of a wider suite of molecular tools.

\section{CONCLUSIONS}

The diversity of Bonamia species is wider than previously appreciated, including 3 valid described species (B. ostreae, B. exitiosa, and B. perspora) plus 3 additional lineages, infecting $O$. chilensis in Chile, O. edulis in California, and D. sandvicensis in Hawaii, that warrant descriptions as new species. The undescribed parasites from $O$. chilensis and $O$. edulis are distinguished from $B$. exitiosa only at the ITS rDNA locus, which we recommend should be used for determination of the species boundaries of $B$. exitiosa as well as other Bonamia species.

The discovery of a Bonamia sp. infecting Hawaiian $D$. sandvicensis underscores the potential for important new observations to emerge when surveys of diversity include little-studied, non-commercial marine fauna. It also raises new questions concerning the evolution of haplosporidian life strategies. Most intriguingly, we might ask whether all Bonamia species, and not just $B$. perspora, may be capable of 'conventional' haplosporidian replication and transmission under appropriate conditions.

Acknowledgements. We thank the many colleagues who assisted with collection of materials. Allen Fraser (New Zealand Ministry of Fisheries), Wilma Blom and Gordon Nicholson (Auckland War Memorial Museum, New Zealand), and Rodney Roberts (Cawthron Institute) performed oyster collections in New Zealand. Susan Laramore and John Scarpa (Harbor Branch Oceanographic Institute) provided the Crassostrea ariakensis from Florida. Jessica Moss Small and Hamish Small (Virginia Institute of Marine Science) provided the Isognomon sp. from Florida. Loren Coen (South Carolina Department of Natural Resources) provided Ostrea stentina from South Carolina. Naoki Itoh (Tohoku University, Miyagi, Japan) provided O. denselamellosa. Nejla Bejaoui (Institut National Agronomique de Tunisie, Tunis, Tunisia) provided Tunisian O. stentina. Marc Engelsma (Central Veterinary Institute, Lelystad, the Netherlands) provided samples of Dutch O. edulis. Gary Meyer provided O. lurida from British Columbia. Rita Crockett and Susan Denny (Virginia Institute of Marine Science) performed all histology. TNT v. 1.1 software was available through the sponsorship of the Willi Hennig Society. This is VIMS Contribution Number 3367. 


\section{LITERATURE CITED}

Abollo E, Ramilo A, Casas SM, Comesana P, Cao A, Carballal MJ, Villalba A (2008) First detection of the protozoan parasite Bonamia exitiosa (Haplosporidia) infecting flat oyster Ostrea edulis grown in European waters. Aquaculture 274:201-207

- Altschul SF, Madden TL, Schäffer AA, Zhang J, Zhang Z, Miller W, Lipman DJ (1997) Gapped BLAST and PSIBLAST: a new generation of protein database search programs. Nucleic Acids Res 25:3389-3402

Burreson EM, Stokes NA, Carnegie RB (2004) Bonamia sp. (Haplosporidia) found in nonnative oysters Crassostrea ariakensis in Bogue Sound, North Carolina. J Aquat Anim Health 16:1-9

Cáceres-Martínez J, García Ortega M, Vásquez-Yeomans R, de Jesús Pineda García T, Stokes NA, Carnegie RB (2012) Natural and cultured populations of the mangrove oyster Saccostrea palmula from Sinaloa, Mexico, infected by Perkinsus marinus. J Invertebr Pathol 110: 321-325

Campalans M, Rojas P, Gonzalez M (2000) Haemocytic parasitosis in the farmed oyster Tiostrea chilensis. Bull Eur Assoc Fish Pathol 20:31-33

Carnegie RB, Cochennec-Laureau N (2004) Microcell parasites of oysters: recent insights and future trends. Aquat Living Resour 17:519-528

> Carnegie RB, Barber BJ, Culloty SC, Figueras AJ, Distel DL (2000) Development of a PCR assay for detection of the oyster pathogen Bonamia ostreae and support for its inclusion in the Haplosporidia. Dis Aquat Org 42:199-206

Carnegie RB, Burreson EM, Hine PM, Stokes NA, Audemard C, Bishop MJ, Peterson CH (2006) Bonamia perspora n. sp. (Haplosporidia), a parasite of the oyster Ostreola equestris, is the first Bonamia species known to produce spores. J Eukaryot Microbiol 53:232-245

Carnegie RB, Hill KM, Stokes NA, Burreson EM (2014) The haplosporidian Bonamia exitiosa is present in Australia, but the identity of the parasite described as Bonamia (formerly Mikrocytos) roughleyi is uncertain. J Invertebr Pathol 115:33-40

Cochennec-Laureau N, Reece KS, Berthe FCJ, Hine PM (2003) Mikrocytos roughleyi taxonomic affiliation leads to the genus Bonamia (Haplosporidia). Dis Aquat Org 54:209-217

Corbeil S, Arzul I, Robert M, Berthe FCJ, Besnard-Cochennec N, Crane MS (2006) Molecular characterisation of an Australian isolate of Bonamia exitiosa. Dis Aquat Org 71:81-85

FAO (2007-2011) Fisheries and Aquaculture Department. Fisheries and Aquaculture Fact Sheets. In: FAO Fisheries and Aquaculture Department [online]. Rome. Updated. Available at www.fao.org/fishery/culturedspecies/Ostrea _edulis/en (accessed 11 February 2011)

Farley CA, Wolf PH, Elston RA (1988) A long-term study of 'microcell' disease in oysters with a description of a new genus, Mikrocytos (g. n.), and two new species, Mikrocytos mackini (sp. n.) and Mikrocytos roughleyi (sp. n.). Fish Bull NOAA 86:581-594

Ford SE, Stokes NA, Burreson EM, Scarpa E, Carnegie RB, Kraeuter JN, Bushek D (2009) Minchina mercenariae n. sp. (Haplosporidia) in the hard clam Mercenaria mercenaria: implications of a rare parasite in a commercially important host. J Eukaryot Microbiol 56:542-551

Goggin CL (1994) Variation in the two internal transcribed spacers and 5.8S ribosomal RNA from five isolates of the marine parasite Perkinsus (Protista, Apicomplexa). Mol Biochem Parasitol 65:179-182

Goloboff P, Farris J, Nixon K (2008) TNT, a free program for phylogenetic analysis. Cladistics 24:774-786

Grizel H, Mialhe E, Chagot D, Boulo V, Bachère E (1988) Bonamiasis: a model study of diseases in marine molluscs. Am Fish Soc Special Publ 18:1-4

Harry HW (1985) Synopsis of the supraspecific classification of living oysters (Bivalvia: Gryphaeidae and Ostreidae). Veliger 28:121-158

> Haupt TM, Griffiths CL, Robinson TB, Tonin AFG (2010) Oysters as vectors of marine aliens, with notes on four introduced species associated with oyster farming in South Africa. Afr Zool 45:52-62

Hill KM, Carnegie RB, Aloui-Bejaoui N, Gharsalli RE, White DM, Stokes NA, Burreson EM (2010) Observation of a Bonamia sp. infecting the oyster Ostrea stentina in Tunisia, and a consideration of its phylogenetic affinities. J Invertebr Pathol 103:179-185

Hine PM, Cochennec-Laureau N, Berthe FCJ (2001) Bonamia exitiosus n. sp. (Haplosporidia) infecting flat oysters Ostrea chilensis in New Zealand. Dis Aquat Org 47: 63-72

> Jozefowicz CJ, Ó Foighil D (1998) Phylogenetic analysis of Southern Hemisphere flat oysters based on partial mitochondrial 16S rDNA gene sequences. Mol Phylogenet Evol 10:426-435

Katoh K, Toh H (2008) Recent developments in the MAFFT multiple sequence alignment program. Brief Bioinform 9:286-298

Kessing B, Croom H, Martin A, McIntosh C, Owen McMillan W, Palumbi S (1989) The simple fool's guide to PCR, version 1.0. Department of Zoology, University of Hawaii, Honolulu, HI

Kirkendale L, Lee T, Baker P, Ó Foighil D (2004) Oysters of the Conch Republic (Florida Keys): a molecular phylogenetic study of Parahyotissa mcgintyi, Teskeyostrea weberi and Ostreola equestris. Malacologia 46:309-326

> Kroeck MA, Montes J (2005) Occurrence of the haemocyte parasite Bonamia sp. in flat oysters Ostrea puelchana farmed in San Antonio Bay (Argentina). Dis Aquat Org 63:231-235

Littlewood DTJ (1994) Molecular phylogenetics of cupped oysters based on partial 28S rRNA gene sequences. Mol Phylogenet Evol 3:221-229

Medlin L, Elwood HJ, Stickel S, Sogin ML (1988) The characterization of enzymatically amplified eukaryotic 16Slike rRNA-coding regions. Gene 71:491-499

Mitchell HL (1966) A simple method of permanent staining of intestinal parasites, using dimethyl sulfoxide. Tech Bull Regist Med Technol 36:45-46

> Morton B, Lam K, Slack-Smith S (2003) First report of the European flat oyster Ostrea edulis, identified genetically, from Oyster Harbour, Albany, south-western Western Australia. Molluscan Res 23:199-208

Narcisi V, Arzul I, Cargini D, Mosca F and others (2010) Detection of Bonamia ostreae and B. exitiosa (Haplosporidia) in Ostrea edulis from the Adriatic Sea (Italy). Dis Aquat Org 89:79-85

Pichot YM, Comps M, Tige G, Grizel H, Rabouin MA (1980) Recherches sur Bonamia ostreae gen. n., sp. n., parasite nouveau de l'huitre plate Ostrea edulis. Rev Trav Inst Peches Marit 43:131-140

Reece KS, Siddall ME, Stokes NA, Burreson EM (2004) 
Molecular phylogeny of the Haplosporidia based on two independent gene sequences. J Parasitol 90:1111-1122

Ronquist F, Huelsenbeck JP (2003) MrBayes 3: Bayesian phylogenetic inference under mixed models. Bioinformatics 19:1572-1574

Shaw BL, Battle HI (1957) The gross and microscopic anatomy of the digestive tract of the oyster Crassostrea virginica (Gmelin). Can J Zool 35:325-347

Shilts MH, Pascual MS, Ó Foighil D (2007) Systematic, taxonomic and biogeographic relationships of Argentine flat oysters. Mol Phylogenet Evol 44:467-473

Stenzel HB (1971) Oysters. In: Moore RC (ed) Treatise on invertebrate paleontology, Part N: Mollusca 6, Bivalvia, Vol. 3. Geological Society of America and University of Kansas Press, Lawrence, KS, p N953-N1224

Stokes NA, Burreson EM (1995) A sensitive and specific DNA probe for the oyster pathogen Haplosporidium nelsoni. J Eukaryot Microbiol 42:350-357

Editorial responsibility: Marc Engelsma,

Lelystad, The Netherlands
Stokes NA, Burreson EM (2001) Differential diagnosis of mixed Haplosporidium costale and Haplosporidium nelsoni infections in the eastern oyster, Crassostrea virginica, using DNA probes. J Shellfish Res 20:207-213

Swofford DL (2002) PAUP* Phylogenetic analysis using parsimony ( ${ }^{*}$ and other methods), version $4.0 \mathrm{~b} 10$ (Alvitec). Sinauer Associates, Sunderland, MA

Tamura K, Dudley J, Nei M, Kumar S (2007) MEGA4: Molecular Evolutionary Genetics Analysis (MEGA) software version 4.0. Mol Biol Evol 24:1596-1599

White DM (2008) A Molecular Phylogeny of the Genus Bonamia based on sequence data of the ribosomal RNA (rRNA) gene complex. Master's thesis, College of William \& Mary, Williamsburg, VA

Wilgenbusch JC, Warren DL, Swofford DL (2004) AWTY: a system for graphical exploration of MCMC convergence in Bayesian phylogenetic inference. Available at http:// ceb.csit.fsu.edu/awty

Submitted: July 29, 2013; Accepted: February 27, 2014 Proofs received from author(s): May 22, 2014 